\title{
A COMPARATIVE APPROACH TO PRIVILEGED PARTNERSHIP: IS TURKEY REALLY DIFFERENT?
}

\author{
ALP KÖKSAL* \\ Boğaziçi University
}

\begin{abstract}
'Privileged Partnership' is a special status supported by a group of European leaders as an ultimate solution for Turkey's integration into the European Union. Although its definition and content remains vague, privileged partnership is a third way of engagement which is something less than full membership and more than regular partnership. This article suggests that the most significant question in order to justify European intentions behind this proposal is to ask if Turkey is really that much different from existing EU member states so that a brand new status needs to be formulated for Turkish enlargement. The research will be based on a comparative study among Turkey and two groups of 'dissimilar' EU member states including new members from Central and Eastern Europe as well as founders of the European integration. A multidimensional and integrated framework will be used and a number of relevant indicators in demographic, political, economic, social and security aspects of Turkey and the selected EU members will be analyzed. Finally, the aim of this study is to clarify whether Turkey is substantially different from the 'old' as well as 'new' EU members and therefore 'privileged partnership' can be justified on rational grounds or whether the proposal of 'privileged partnership' is based on normative factors and it is an indicator of the EU's bias against Turkey's full membership due to cultural and religious differences.
\end{abstract}

Keywords: Turkey's EU membership, privileged partnership, EU - Turkish relations, enlargement, European Union.

\section{IMTIYAZLI ORTAKLIĞA KARŞILAŞTIRMALI BIR YAKLAŞIM: TÜRKIYYE GERÇEKTEN FARKLI MI?}

\begin{abstract}
ÖZET
“Imtiyazlı Ortaklık,” Türkiye’nin Avrupa Birliğ̈i’ne katılım sürecinde ortaya atılan ve entegrasyon için nihai sonuç niteliği taşıyabilecek özel bir statüdür. Tanımı ve içeriği belirsiz olsa da AB üyeliğinden daha düşük fakat sıradan bir ortaklıktan daha yüksek derecede bütünleşme sağlayacă̆ d düşünülebilir. Önemli olan soru, bugüne kadar AB'ye başvuran tüm ülkelere vaat edilen tam üyelik statüsü söz konusu aday Türkiye olduğunda neden özel bir ortaklık olarak değişmektedir? Bu makalede sorgulanan ana fikir, rasyonel değerlerle incelendiğinde Türkiye’nin gerçekten Avrupa Birliği ülkelerinden ve de özellikle yeni üyelerden, $A B$ 'ye tam üye değil de sadece bir ortak olabilecek derecede farklı olup
\end{abstract}

* Alp Köksal is a Ph.D. candidate in the Department of Political Science and International Relations at Boğaziçi University, 34342, Bebek, İstanbul, Turkey. E-mail: alpkoksal@gmail.com

Boğaziçi Journal Vol. 25, no. 2 (2011), pp. 27-57. 
olmadı ̆̆ konusudur. Araştırma, iki gruba ayrılmış 'farklı'AB ülkelerinin Türkiye ile olduğu gibi kendi

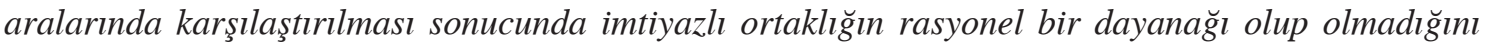
açıklamayı amaçlamaktadır. Belirli AB üyeleri ve Türkiye’nin demografik, ekonomik, politik, sosyal ve güvenlik alanlarından seçilen ampirik göstergeleri çok boyutlu ve entegre bir çerçeve dahilinde karşılaştırılacak ve analiz edilecektir. Sonuçta bu karşılaştırma Türkiye’ye sunulan imtiyazlı ortaklık önerisinin arka planında rasyonel farklılıklardan oluşan bir temelin mi yoksa tamamen kültürel ve dini farklılıklar gibi normatiffaktörlerin mi bulunduğu sorusunun cevaplanmasına yardımcı olacaktır.

Anahtar kelimeler: Türkiye'nin Avrupa Birliği ïyeliği, imtiyazlı ortakllk, AB - Türkiye ilişskileri, Avrupa Birliği’nin genişlemesi, Avrupa Birliği.

"Privileged Partnership" is a special status proposed for Turkish accession to the European Union, supported by a group of important European leaders and presented as an ultimate solution for Turkish integration. However, the content of such a special partnership remains vague and the question should be asked why a new model is offered by European authorities as an end result of the negotiations with Turkey, instead of aiming for full membership which has been offered to every other candidate in the European Union's history. Turkey is a unique country in many aspects which makes comparison to other EU candidates or member states a difficult process. Nevertheless, European motives behind the formula of Turkey's privileged partnership can be understood by conducting a systematic comparative research between Turkey and the present members of the European Union. This article suggests that the most significant question in order to justify European intentions regarding the proposal of privileged partnership is to ask if Turkey is really that much different from EU member states and especially from the new members from Central and Eastern Europe so that a brand new status needs to be formulated for Turkish enlargement.

On October 3, 2005, Turkey officially started open-ended negotiations for membership in the European Union which could result in the biggest enlargement of EU history. Turkey has so far accomplished a series of comprehensive legislative and constitutional reforms on its determined path towards becoming a part of Europe. Turkey's relations with the EU have been a catalyst for the transformation of the Turkish economy, social policy, civil policy, legal system and political system with an aim to reach European standards for achieving full membership in the Union. However, Germany's Christian Democrats have suggested a new model of 'privileged partnership' which would provide Turkey with free trade and closer integration in security and military affairs but not full membership. Besides granting membership or rejecting Turkey, privileged partnership is a third way of engagement for Turkey with the Union. The definition of privileged partnership remains unclear, but it is clearly something more than a partnership but less than a full membership. The characteristics of such a partnership are only theoretical and ambiguous as the privileged partnership status has not been practiced before and hardly defined by any party who proposed it so far. Although most Turks believe that privileged partnership simply intends to keep Turkey out of the Union, leaders of Germany, France, Austria and many Europeans affiliated with the Christian Democrat worldview believe that it is the only possible solution for Turkish integration.

Indeed, Turkey and the EU have their obvious socio-cultural and religious differences. A majority of Turkey's inhabitants have a different religion from the rest of the EU members, Turkey has a large and relatively poor population and more importantly from a sociological perspective it has been the 
historical "other" for the European identity for centuries. Even though the case of Turkey's accession to the European Union is unique, Turkey's uniqueness does not constitute a basis for a special status that could be an alternative to full membership as long as Turkey fulfills the EU membership conditionality (Aybet, 2006: 547). The Copenhagen Criteria is built on rational grounds and it suggests that any candidate country which has a geographic proximity with Europe can become a full EU member when it fulfills the conditionality. More importantly, all candidate states shall be treated equally as the principle of 'pacta sunt servanda' foresees that all agreements are to be honored and so does the European commitment to Turkey's full membership, on equal grounds with the previous candidates. Therefore, the reasons for proposing a privileged partnership instead of full membership and the questions of double standards within the EU can be examined by comparing Turkey with the present European Union member states. In fact, the Central and Eastern European Countries (CEECs) which have joined the EU on the last rounds of enlargements in 2004 and 2007 are known to have both a far limited experience of democracy and more volatile economies than Turkey. A systematic comparison of Turkey with CEECs will provide better grounds for judging the popular Turkish claim of double standards within the EU.

If privileged partnership is to be imposed by the EU as the only option to European integration for Turkey, it will raise questions about European bias against Turkey's full membership because of ignoring Turkey's progress in all spheres of conditionality especially in the last decade. The question is simple: why did the goal of full membership evolve into a new status of privileged partnership during the negotiations? Is Turkey really that much different from the European Union member states including the Central and Eastern European countries according to the rational membership criteria? If this is not so, Turkey's privileged partnership rather than full membership to the EU can be justified. From a rationalist perspective, the EU would be right to propose for Turkey something other than full membership if Turkey is significantly different from other EU member states and lagging behind in fulfilling the Copenhagen criteria which the CEECs managed to achieve. Otherwise, arguments for double standards within the European Union based on cultural and religious differences between the two societies would prove to be correct, and the EU would lose great credibility in international affairs due to discriminating against Turkey on culturalist grounds. This study aims to bring answers to these specific questions by taking a comparative approach with an aim to either justify the European proposal of privileged partnership or conclude that Turkey is not radically different from other EU member states and therefore the European Union is biased against Turkey's full membership.

\section{METHODOLOGY}

The following section will outline the methodology for this study. The most appropriate technique for the research question presented in this study is the comparative method in the form of a mid-scale crosscase analysis which entails both statistical data and theoretical narrative. The comparative method offers a broader range of information about the issues and allows the researcher to pose questions that data from a single country or single case study cannot answer. From a methodological point of view, Schimmelfennig and Sedelmeier (2002) indicate that the state of research on European enlargement studies is often of a limited and narrow scope. Enlargement literature demonstrates the limits of singlecase studies that are mostly descriptive. Even if they are theory-oriented, there is a growing need for an enlargement of the research on 'enlargement.' In fact, an enlarged European Union can only be analyzed by conducting larger scale comparative studies on European enlargement (Schimmelfennig and Sedelmeier, 2002). This study aims to provide a comparative analysis of Turkey and a number of 
European Union members. Rather than a single case analysis, a multidimensional framework will be used, focusing mainly on an EU macro-polity level as well as candidate and membership politics and impacts of EU conditionality on both Europe and the applicant state Turkey. Both quantitative and qualitative analyses will be conducted which are a mixture common in comparative analysis. Thereby, instead of a single approach to causal analysis, a wide range of strategies of causal inference will be employed for capturing the bigger picture. Finally, cross-national research will be a valuable tool for comparing the EU members in order to understand diversity in the EU and how much Turkey is different from specific European states.

This research will involve simultaneous use of two different strategies developed for the comparative method. Both 'most similar systems design' and 'most different system design' will be used in two separate groups of EU member states in order to better observe the variance between Turkey and the EU at different levels as well as the differences among European Union member states so as to understand the established limits of toleration for full membership. The quantitative analysis will involve a total of thirteen EU member states divided in two groups in addition to Turkey and the EU average figures. The first group will consist of five and the second group will consist of eight European states. In the first group, Germany, France, the United Kingdom, Italy and Spain will take place. These are the five largest states of the EU in terms of population and they are also the most politically influential states in the Council of the European Union according to the Treaty of Nice which gives member states voting powers on a direct population dependent condition. Indeed, prior to the adjustment in the composition of the European Commission which became effective by 1 November 2004, these five states were the only members to have two commissioners in the European Union's executive body. Therefore, these larger and relatively older members of the Union are expected to have an important influence over the decision-making mechanisms of the EU regarding Turkey's accession. The United Kingdom and Spain are known as the two influential states that favor Turkey's full membership. On the contrary, the leaders of France and Germany have publicly announced their opposition to Turkey's full membership to the European Union. In fact, the German Chancellor Angela Merkel and French President Nicolas Sarkozy are the two leading figures in European politics who most support the idea of the Union's privileged partnership with Turkey. Finally, the EU members in the first group are expected to have a greater difference from Turkey considering that they are among the most developed states in the European Union.

On the other hand, EU members in the second group are expected to have somewhat similar characteristics to Turkey as they are newer entrants compared to the ones in the first group. Also, they are relatively smaller in population and therefore will have less influence in European politics according to the Council voting design. The second group consists of Romania and Bulgaria as the latest members of the EU in 2007, Poland as the largest of the 2004 entrants in addition to Lithuania, Latvia and Estonia which are among the CEECs with a relatively low democratic heritage, Cyprus, a key political subject in Turkey - EU relations and finally Greece which is the neighbor as well as the historic rival of Turkey, often compared with Turkey in major EU related studies. After all, these states have experienced various problems during their individual paths to European integration, thus they are expected to be in a similar position to Turkey's regarding the period of membership negotiations.

Turkey in comparison to the EU members in both groups will be evaluated in five subfields: political, economic, social, security and demographical dimensions of integration. Among the two possible outcomes of this study, a) if there is a convergence between the data on Turkey and the second group's 
data which is more apparent than the variance between the two groups, then the first scenario would support the argument of "double standards" in Europe, as privileged partnership would more likely to be proposed on the basis of cultural and religious differences. On the other hand, b) if there is reasonable convergence between the indicators of the first and the second group of EU members and an important divergence between Turkey's data and the European states' data in both groups, then one can rationalize why Turkey is treated specially by the Europeans as not a potential full member today. The majority of secondary data to be used in the analysis are collected from the "Eurostat," which is the source of official statistics on the European Union published by the EU Commission. In addition to Eurostat, data obtained from the European Union Commission's "Eurobarometer," "World Values Survey," "International Monetary Fund Statistics," "World Economic Forum," "Idea: International Institute for Democracy and Electoral Assistance," "Freedom House," and "UNdata" are used to fill in the blanks and increase the validity of the secondary sources used as the major input to this study's empirical analysis. Further information on the sources of data for each indicator and the years of the data collected is available in Appendix B.

\section{ANALYSIS, FINDINGS AND RECOMMENDATIONS}

This section is organized in five subfields: Demographics, economics, politics, security and social dimensions of Turkey's integration to the European Union in order to cover all aspects of TurkeyEU relations from a multidimensional comparative perspective; these together would provide better grounds for justifying the proposal of a privileged partnership to Turkey. The statistical data used in the narrative below is presented in Appendix A. Unless noted otherwise in the text, the years as well as the source of data for each indicator used in the tables is presented in Appendix B.

\section{Demographics}

Turkey is an exceptionally large country in comparison to other European Union member states regarding both population and surface area. The accession of Turkey will mean the largest enlargement in the EU history in terms of area. In fact, Turkey's surface area of 783,562 $\mathrm{km}^{2}$ is larger than the total size of the 2004 enlargement which resulted in accession of ten new member states, and the greatest enlargement in the EU history so far. These ten new member states had a total population of $74,722,000$ people by that time, roughly equal to the population of Turkey today. By looking at the relatively high population growth rate of Turkey which is $1.31 \%$ per annum, Turkey is also expected to be the largest enlargement in terms of population at time of its future accession.

In the first group of most populated EU member states, France stands out as the largest country in land with $643,548 \mathrm{~km}^{2}$, while the United Kingdom is the smallest country with its $244,820 \mathrm{~km}^{2}$ surface which corresponds to less than one third of Turkey's size. On the other hand, when population is considered, Germany is the largest country of the EU with its 82 million inhabitants. Although Spain has a large territory which makes up $11.4 \%$ of the EU land, its population is relatively low at $45,828,172$ inhabitants that corresponds to $9.2 \%$ of total EU population. The United Kingdom is the most densely populated country in the first group where $12.3 \%$ of EU citizens live in a land of 5.5\% of the Union. In the second group which consists of Greece, Cyprus, Poland and some of the Central and Eastern European Countries (CEECs) including the latest members Romania and Bulgaria, Poland is the largest country both in population and in surface area of over 38 million inhabitants in 321,685 $\mathrm{km}^{2}$, which corresponds to $7.6 \%$ of EU population living in $7.1 \%$ of the European Union land. On 
the contrary Cyprus is predictably the smallest in both area and population with its 796,000 people living in an area of $9,250 \mathrm{~km}^{2}$ which only make approximately $0.2 \%$ of the EU. It is noteworthy that the CEECs which joined the EU in 2004 are very small in size and population, having a land area around $1.5 \%$ and population below $1 \%$ of the EU per country. On the other hand, the 2007 entrants of Bulgaria and Romania are larger in size and population but their sum still makes less than half of Turkey's population and surface area. At the end, Turkey has a population of 71,517,000 according to the records of the EU and this corresponds to $14.3 \%$ of the total European Union population which is 499,723,520 today. Therefore, before anything else, one can conclude that Turkey is a large country, a big bite to swallow for the European Union only in size without even considering economic, social and cultural factors.

Moreover, considering that decision-making mechanisms in certain intergovernmental policy areas at the European Union level are linearly correlated to the size of member states' populations, Turkey with its large size will have more influence on European policy-making than less populated countries such as France and the UK, a situation which the great powers of the EU will never accept. Therefore, Turkey's size in population has critical importance for the European Union's internal power balance and it is more realistic to expect that Turkey may then never become a fully equal member in terms of decision-making powers parallel to its population. On the other hand, another important issue about Turkey's size is EU's structural funds and the Common Agricultural Policy (CAP). First of all, if Turkey becomes a member, such a large yet relatively poor country will require a lot of investment as well as additional structural fund allocation from the present EU members in order to close the gap between the standards of Turkey and the Union. Because budget allocation in most policy areas depends on the size of the member state, Turkey is most likely to receive the greatest amount from the European Union budget in many policy areas including the CAP, which alone accounts for almost half of the EU budget. After all, the large size and population of Turkey may seem like a burden to present EU members, and no state would agree to get that heavy weight on their shoulders unless Turkey really has important benefits to offer to the project of European integration.

Turkey's population is growing even bigger and the data suggests that it will get ahead of Germans in several years; so by the time Turkey becomes a member it would be the most populated state in the European Union. Turkey's annual population growth rate is $1.31 \%$, which is considerably high compared to the European average of $0.131 \%$. All countries included in this study have growth rates smaller than Turkey, while negative growth rates in members of both groups imply an actual decline of population in the EU including Germany and Italy in the first group. In fact, an important pattern that can be observed from the data is that populations in all CEECs are declining. The growth of Turkish population as the CEEC's populations decline can become a comparative advantage in economy if the Turkish labor force can be utilized to produce a higher growth of GDP. Turkey has a labor force of over 24 million, which is comparable to the size of the labor force in Italy, Spain and France while the UK has a labor force of 31,200,000 and Germany has the largest labor force in the EU which consists of 43,600,000 people. According to the nature of its labor force, Turkey is similar to Poland and Romania, as a large part of its work force is officially employed in agriculture (Derviş et al., 2004). Although one quarter of Turkey's labor force is still employed in agriculture today, the employment share in agriculture has declined radically since those days when half of Turkey's total labor force was working in agriculture. Nevertheless, low labor utilization points to the unused potential of the Turkish economy. Of the German population, 53\% is utilized as labor while the same percentage is only 33 in Turkey. Even a more critical point is that only one out of four women work in Turkey, whereas nearly $60 \%$ of women that live in EU countries contribute to the workforce (Eurostat, 2007). Therefore, 
one can conclude that Turkey needs to further utilize its labor force and include more women in the workforce in order to take advantage of its large population for greater economic benefits.

On the other hand, when there is excess labor due to low utilization of the work force in a country, the issue of migration comes to mind. Turkey's net migration rate is 1.588 per 1000 people which suggests that Turkey receives more immigrants than it sends to other countries. In the first group, only Germany has a negative migration rate while the ratio goes up to 6.367 immigrants per 1000 French citizens. In the second group of EU members that have relatively less developed economies, negative migration rates suggest that citizens of these countries migrate to other countries such as 4.627 out of every 1000 Lithuanian do. After all, the EU receives 1.879 migrants per 1000 Europeans and this ratio is similar to the net migration rate of Turkey. Many Europeans fear that if Turkey becomes a full member of the European Union, large numbers of Turkish labor will begin immigrating to the EU. Given the importance of the EU as an anchor in Turkish politics as well as economy today, it could be that migration might be even greater if the prospects of Turkish membership to the EU are lost (Erzan and Kirişci, 2004). The European experiences of Greek, Portuguese and Spanish integration to the Union indicate that a successful accession period with effective implementation of legislations and reforms have created high growth in domestic economies thus gradually eliminating migration from new member states into Western Europe (Erzan et al., 2004: 11).

Finally, the chances for immigration can even be approached as an opportunity for European countries to cope with the consequences of their aging populations (Vatanen, 2006). It is most likely that the full mobility of workers might only come twenty or more years after Turkish accession and by that time the European labor markets will be strongly affected by the aging population. Therefore, Europe might face labor shortages in the future looking at the current demographic trends, and migration might not be seen as such a harsh problem at that time. In addition to the large Turkish population and its relatively high growth rate, data suggest that population in Turkey is also very dynamic. The median age is 27.7 , which means that the Turkish population is significantly young compared to the EU median age of 40.3. Once again, the dynamic and large population of Turkey could become an important advantage on its path towards EU membership, but it is critical that the young population be utilized in the labor force first.

\section{Economics}

Turkish economy undertook important reforms in recent years to fulfill the Copenhagen economic criteria. Although Turkey is a large country in size as well as population, its current GDP is 437,252 billion Euros, which is substantially lower than the GDP of all large countries in the first group. Germany has the highest GDP of 2,404,000 billion Euros which stands for 19.8\% of European Union's total economic output of 12,168,498 billion, while Turkey's GDP is only $3.6 \%$ of the GDP of the EU. In the second group, Turkey's economy is significantly larger than all others. Considering that Turkey is a lot bigger than these states in size and population, this does not mean that Turkish economy is more efficient. However, it is true that Turkey is a more important economy than EU members in the second group due to its market size and potential.

After the recent global economic crisis, the GDP growth rate of almost every country displays negative figures. Although all of the economies in the first group reflect negative growth, Turkey's rate of $-5.8 \%$ means that Turkish economy has shrunk more than any other economy in this group in 2009 . 
Because of the fast and remarkable economic growth Turkey managed to achieve in the last decade, the impact of this high negative growth rate was less noticeable in the positive economic environment in Turkey. On the other hand, economies in the second group indicate mixed growth rates for the same year. Cyprus and Greece, before the recent financial crisis, have smaller negative values close to zero, which is better than the most developed economies in the first group; while Poland has a positive GDP growth rate. Contrarily, the newest two members of the EU, Bulgaria and Romania, indicate larger negative growth compared to Turkey, whereas the economies of Estonia, Latvia and Lithuania have shrunk much more as their growth rates increased to -18\%. Turkey's -5.8 GDP growth is worse than the EU average of -4.1 for 2009 but the Turkish economy is still more stable compared to the economies of the latest EU members. Finally, it must be highlighted that the GDP growth of Turkey in 2010 is measured as $9.0 \%$, which is significantly higher than any other country in the European Union and a great success for Turkey considering that the average GDP growth rate for the EU was $1.9 \%$ for the year 2010 (Eurostat).

The GDP per capita income in Turkey is $\$ 10,479$, which is significantly low compared to larger European economies in the first group. Among the countries included in this study France has the highest GDP per capita income at $\$ 46,037$, while only the latest members, Romania and Bulgaria, have per capita incomes lower than the Turkish average. The rest of the countries in the second group all have higher per capita incomes in comparison to Turkey, although their GDP per capita is substantially lower than members in the first group. When these nominal values are adjusted to purchasing power standards, data indicates that Germans are the wealthiest with a GDP per capita which is $12 \%$ higher than the European Union average while Bulgarian GDP per capita stands for only $39.8 \%$ of the average European income. Turkey's GDP per capita corresponds to $43.2 \%$ of European standards, which means that an average European is more than two times wealthier than his or her Turkish equivalent.

Even though Turkey can only meet Bulgarian or Romanian standards in per capita income within the European Union, a rapid convergence of GDP per capita might be possible in theory due to Turkey's young labor force, considering that the proportion of the working age in Europe is not rising (Derviş et al., 2004: 103). Therefore, it can be argued that Turkey's biggest potential advantage in economy could be activated with a better utilization of its human resources. On the contrary, unemployment in Turkey is relatively high at $13.1 \%$ while unemployment in the EU is $9.5 \%$. Among the countries in the first group, all have unemployment rates below $10 \%$ except Spain which indicates enormous unemployment at $19.4 \%$, even higher than all CEECs except Latvia. In the second group, Romania and Bulgaria have unemployment rates comparable to the EU members in the first group; but Estonia, Latvia and Lithuania suffer from higher unemployment than Turkey's 13.1\% (Eurostat, 2009). Although the unemployment rate in Turkey is at $9.1 \%$ today according to the Turkish Statistical Institute Report No: 214 (TUIK, 2011), it does not seem to converge with the European norms regardless of efforts made in line with Turkey's undergoing economic transformation.

Labor productivity per person employed is among the structural indicators chosen by the European Commission for measuring efficiency of an economy. If GDP in 'purchasing power standards' per person employed relative to the EU average is taken as $100 \%$, the productivity of a Turkish worker is measured to be $60.3 \%$ of an average European worker in 2009, and $62.3 \%$ in 2010 according to Eurostat. As one might easily guess, all countries in the first group have over 100\% labor productivity, the French worker being the most productive with $115.2 \%$ of EU average (2010). However, in the 
second group the picture is rather different, especially in the CEECs which have labor productivity below the Turkish level. Although Greek labor in 2010 was productive at a rate of $95.9 \%$, Bulgarian workers were the least productive with their $41.5 \%$ ratio, while Turkey was almost equal to Poland in this indicator. Therefore, if Turkish workers are to compete with their European counterparts, Turkey must upgrade the way it produces skills in its labor force. Indeed, statistics suggest that high level of labor productivity is already attained in the small modern sector of the Turkish economy which can create a great opportunity for rapid growth (Derviş et al., 2004: 106-110).

On the contrary, the adoption of the EU legislation on employment is likely to put a burden on both Turkish corporations and workers that will need to adapt to a new competitive environment. It should be noted that the informal economy in Turkey is quite large compared to European countries and the productivity of this large part of the Turkish economy remains off the record in the Eurostat statistics above. Turkey is also known to have many other problems with labor law and practice such as the longest working hours, 52.2 hours in Turkey vs. 40.4 hours in EU according to Eurostat 2011, highest number of work accidents, considerably high number of workers without social security, a high dismissal rate from a job without a justified reason and lowest rate of collective labor bargaining. Although Turkey has already started to change its institutional structure for employment and social affairs to harmonize with the EU in accordance with the European directives, further reforms are obviously needed in the labor law and other related regulations to fully comply with the EU acquis communautaire (Özler and Taymaz, 2005).

Total investment in the Turkish economy equals $15.9 \%$ of Turkey's GDP which is relatively low when compared to the EU average of $19.2 \%$. Total investment in Turkey is only higher than the United Kingdom, close to Greece and lower than all other countries in this study. Interestingly, while larger and developed economies stay around 20\%, CEECs have higher investment rates up to $30.7 \%$ in Romania and $27.2 \%$ in Bulgaria which indicate efforts for economic transformation in the latest members of the EU. Therefore, Turkey should follow the CEECs in investment strategies as it desperately needs to attain a higher investment rate to fill the gap between Turkish and European economic standards. Turkey has a relatively low government deficit of 2.2\% of its GDP when compared to EU members in both groups: the UK has a 5\% deficit while Greece has a deficit of 9.8\% (2008). On the other hand, Bulgaria has a budget surplus of $1.8 \%$ while Germany does not have a budget surplus or deficit. The average European public debt ratio is $61.5 \%$ and Spain has the largest debt equal to $105.8 \%$ of the country's GDP. Interestingly, CEECs have substantially lower debts around $10 \%$ and Estonia's public debt is only $4.8 \%$ of its GDP. Considering that larger European economies have higher public debts, Turkey's $39.5 \%$ is almost identical to Spain's ratio. On the contrary, Turkey has a much larger foreign debt compared to the new EU members. Indeed, the record of Poland which underwent turbulent periods over the last decade with deep structural change seems positively stable when compared to the unstable economy of Turkey's past (Derviş et al., 2004: 66-67).

Many established economies such as the United States are known for their long-lasting trade deficits. In the first group of European states, Germany as an important global exporter has a trade surplus of 177,530 million Euros while all other countries in both groups have trade deficits parallel to the size of their economies. The UK has a trade deficit of 117,800 million Euros; whereas the trade balance of the EU is also a negative figure of $-258,480$ million. Turkey has a trade deficit of 48,974 million Euros, similar to the deficit of Greece. Turkey is more advanced than most of the new EU member states in trade integration as the Customs Union arrangement between Turkey and the EU has been 
functioning as a technical success since 1995, long before CEECs signed an accession agreement with the European Union (Gros, 2004). The EU membership will have little impact on Turkey in terms of trade integration because most of the major steps have already been taken (Francois, 2005: 123). Indeed, Turkey is the first country in the European integration project which joined the Customs Union without being a full member of the EU (Y1lmaz, 2002: 107).

Low inflation is an important component of EU conditionality and it has long been a problem for Turkish economy. Although inflation in Turkey is down to $6.3 \%$, which is incredibly low for a country that experienced inflation rates above $100 \%$ in the last fifteen years, it is still high compared to EU norms. The average inflation rate in EU is only $1 \%$ while France, Germany and Italy in the first group have inflation below this level and Spain has negative inflation. Turkish inflation is only comparable to Romania and Lithuania in the second group; which indeed have lower inflation rates at $5.6 \%$ and $4.2 \%$ respectively. High inflation in Turkey is often associated with economic instability and this may be perceived as a threat by European economists because absorbing such a large-scale yet poor and unstable economy may trigger economical instability in Europe, a risk which the Europeans would never accept taking at time of a global economic crisis.

Finally, macroeconomic challenges for Turkey remain substantial. In order to fulfill the Copenhagen economic criteria for becoming a full member of the European Union, Turkey must still attain macroeconomic stability, adopt the EU's 'Common Agricultural Policy' and liberalize its services and network industries. Turkey needs to reduce its annual inflation rate to about $3 \%$, meanwhile attaining sustainability of the current account in trade balance, achieving stable growth in real income and decreasing the unemployment rate to European standards (Ersel and Togan, 2005: 19). If foreign investment inflows can be increased with correct policies of the Turkish government, it would both contribute to employment creation and further improve debt dynamics. (Airaudo et al., 2004: 17-19). The Customs Union can be widened by incorporating areas such as services and agriculture, and deepened by refining arrangements for overcoming its shortcomings (Ülgen and Zahariadis, 2004: 2930). The widening of the Customs Union would allow progressively freer trade of services, therefore it could provide substantial economic benefits to both Turkey and the European Union (Derviş et al., 2004: 109).

While the process of European Union integration proved to have the potential for fundamentally transforming the Turkish economy, Turkey should not wait for the external force from the EU for implementation of economic reforms but it must resolve the sources of past instabilities on its own (Winkler, 2005). After all, improving social policy and labor rights is central to accomplishing further economic progress in Turkey because better utilized, higher-skilled, more productive and efficient labor can only be attained in an environment where social policy and employment rights are well founded. In fact, Chapter 19 of the Turkey-EU negotiations framework which includes social policy, employment rights, anti-discrimination and equal opportunities for women and men has not yet been opened five years after the screening was completed in 2006. This is due to high incompatibility and considerable adjustment costs needed in order to adapt the social conditions at work in Turkey to standards of Europe as well as the European Union acquis.

\section{Politics}

The idea of Turkey's privileged partnership with the EU can be associated with the Christian Democrats, who are against Turkey's full membership in the Union. According to a news article in 
Die Welt, Angela Merkel wrote a letter to EU Commissioners, chairmen of other center and right wing political parties and leaders of all EU member state governments in which she argued that Turkey's privileged partnership was a better option than its full membership in the Union (17 September, 2004). Indeed, former chairman of the Christian Social Union (CSU) Edmund Stoiber once stated that "there must be a limit to European Union enlargement which is not the Turkey-Iraq borders" (Financial Times, 16 May, 2002). Former president of the European Parliament (2007-2009), former chairmen of the largest political block in the European Parliament, European People's Party (1999-2007), and also a member of CDU, Hans-Gert Pöttering expressed his opinion on Turkish integration and advocated a 'strategic partnership' of Turkey by adding that "Turkish full membership would be a mistake for the EU" at the time of his Parliament presidency (Zaman, 28 May, 2009).

Today, Merkel's greatest supporter for advocating a privileged partnership for Turkey is France's President Nicolas Sarkozy, who used to be the leader of Union for a Popular Movement, also affiliated with Christian Democrats. France and Germany have traditionally been the two rivals for leadership in European integration but when it comes to Turkey's candidacy they unite their powers against Turkey's full membership. Although it is a Mediterranean country, Berlusconi administration in Italy was also associated with Christian Democrats and therefore less likely to support Turkey's full membership. On the other hand, political power in the United Kingdom and Spain are not with Christian Democrats. Indeed, the UK and Spain have traditionally supported Turkey's accession to the European Union. The UK's official line has always been to favor further enlargement over deepening of the EU to prevent the Union from growing too powerful at the expense of national sovereignty. Although the Conservative Party assumed power after the Socialists in 2010, the current Prime Minister of the UK, David Cameron, disbanded the Party's ties with Christian Democrats of other European states and left the European People's Party in the European Parliament, leading the formation of European Conservatives and Reformists as a new parliamentary group. On the other hand, Spain as a Mediterranean state supports Turkey as it sees the full membership of Turkey as a potential balance against the twelve countries that joined the Union in the last two rounds of enlargements. In the second group, Greece has manifested goodwill toward Turkey's full membership, apparently hoping to resolve a number of outstanding issues with Ankara through a supportive role including the issue of divided Cyprus. On the contrary, Cyprus opposes Turkey's full membership even though its influence in the EU as well as its ability to act independently from Greece seems to be limited. With the exception of Estonia which is ruled by the Reform Party affiliated with European liberal democrats, the rest of the states in the second group including CEECs are ruled by political parties with Christian Democrat affiliations, which means they are more likely to support the idea of Turkey's privileged partnership from an ideological point of view. After all, the party of the Christian Democrats named the European People's Party has 266 of 735 seats in the European Parliament and it is the largest group in the House.

Outcomes of a comparative analysis of Turkey and EU members regarding the political criteria of membership conditionality support the proposal by Christian Democrats. The quality of Turkish democracy has always been an issue in the long history of EU-Turkey relations. Since the European Union has evolved into more of a political union in recent decades, the stability and eminence of democracy in Turkey emerged as the key obstacles for Turkey's EU membership. Meanwhile, with an aim to become a member of the Union, Turkey has experienced massive efforts of democratization especially during the last ten years. The Turkish Parliament has made a number of important legal and constitutional changes to upgrade Turkish democracy in accordance with European standards (Aydın and Keyman, 2004). However, indicators of democracy in this study illustrate that the quality of Turkish democracy is still substantially below European standards. 
Turkey's score on the Freedom House democracy index is 5.7, while the closest value to Turkey among the countries in the first group is Italy's 7.73, which is not near at all considering that other countries in the first group all have values above 8 while no country in this study including the CEECs have a democracy index below 7. Furthermore, Turkey is clearly lagging behind in political rights and civil liberties according to the evaluation of Freedom House. All EU members in the first group have top scores in political rights and civil liberties with exception of Italy's score of 2 in civil liberties, and the two latest members Bulgaria and Romania have the lowest score of 2 on a scale of 7 in both categories. Unfortunately, civil liberties and political rights in Turkey are rated both at three out of seven, which suggests that there is a great difference even between Turkey and Romania, and as large as the difference between Bulgaria and France. Moreover, the Freedom in the World Report 2009 indicates further problems over Turkey's democratic rule by placing Turkey in the "partly free" category rather than "free" which all European Union member states belong to.

A critical aspect of democratization in Turkey involves the changing role of the Turkish military. The military's political role in the past was regarded as a major obstacle to the consolidation of democracy in Turkey (Güney and Karatekelioğlu, 2005: 451). The Turkish military has traditionally been the guardian of the regime, the protector of the political status-quo which often blocked intensive reforms with an aim to maintain the stability of the system. Its intervention in the Turkish political arena in form of coup d'états in 1960, 1971 and 1980 and a softer intervention in 1997 demonstrate that the military has been one of the most important actors in Turkish politics. In fact, Greece experienced a coup in 1967 followed by a military regime for seven years. This did not create a problem for EU membership, as Greece became a full member in 1981, shortly after the country turned back to democratic rule. However, the impact of military influence on Turkish politics is deeply rooted and has existed longer than it did in Greece. The political reforms undertaken for supporting the EU accession process have downscaled the Turkish military's influence on politics only in recent years (Narbone and Tocci, 2007).

Turkey has a significantly higher government involvement in religion (GIR) value of 47.1 while the European Union average is 19.57. In the first group, the UK and Spain have the highest GIR around 27 , while in Italy this value goes down to 13 . In the second group, Bulgaria gets relatively close to Turkey with 36.72 while GIR in Estonia is only 3.52. Therefore, there is no visible pattern among CEECs in terms of GIR activity, but Turkey stands out from the crowd with its exceptionally high government involvement in religion. On the contrary, if voter turnout is considered as an indicator of democratic activity, Turkey's $84.16 \%$ turnout in 2007 parliamentary elections is higher than all of the most developed European democracies in the first group and substantially higher than the European average of $71.21 \%$. However, one should not overlook the fact that there is a penalty fee in Turkey for not going to polls. Furthermore, Turkish experience in the past military dictatorships that obliged everyone to vote in elections may very well have an influence on the high voter turnout in Turkey today. In the second group, only Cyprus and Lithuania have greater voter turnouts than Turkey, but considering that their populations are incomparably smaller in size, the voter turnout in a country as large as Turkey is noteworthy.

Eurobarometer suggests that none of the EU members included in this study trust their national governments more than the Turks do. Only 32 out of 100 Europeans trust their national governments while $57 \%$ of Turkish people have trust in their government. On the contrary, the level of trust goes 
down to $21 \%$ in a developed democracy such as the United Kingdom while only 10 out of 100 Latvians trust in their government. Nevertheless, when it comes to trust in the EU, Turkish opinion is more skeptical. An important political barrier for Turkey's integration to the EU is the lack of deep commitment to EU membership of powerful circles within Turkey, due to inherent suspicion that the kind of reforms demanded by the Union would lead to a disintegration of the Turkish state (Öniş, 2004: 511). As the West had once attempted to break up the Ottoman Empire, this interpretation and fears of Turks are referred to as the "the Sèvres Syndrome" (Çarkoğlu and Kirişci, 2003). Cosmopolitan processes of democratization motivated by a transnational actor such as the European Union are commonly perceived by Turkey's political elites as a threat to national sovereignty. As a result, the increasingly uncertain political environment harms Turkey's reforms and the integration process to the EU. However, in the age of globalization Turkey is more dependent upon the global processes that are perceived as a threat to national sovereignty. In fact, in this regard, a transformation of the Turkish political structure to reach the EU standards and norms offer the means by which Turkey can safeguard national integrity in today's international conjuncture (Rumford, 2003: 389).

Democratic transformation driven by EU conditionality created a more politically stable and internationally robust Turkey. Recent reforms created the possibility of making Turkish modernity more liberal, plural and multicultural by transforming Turkish democracy into a more consolidated, substantial and deepened mode of governance (Aydın and Keyman, 2004: 13). Therefore, it is correct to argue that the prospects of full membership to the European Union has played a key role in transforming Turkey's state-centric polity into a more democratic, stable and pluralist one especially in the postHelsinki period (Keyman and Öniş, 2004: 27). On the other hand, Turkey's success in implementing structural reforms for consolidation of democracy critically depends on the EU's treatment of Turkey as a potential full member (Baban and Keyman, 2008). Indeed, many believe that the Europeans often failed to demonstrate unambiguous commitment in support of Turkish membership based on mainly cultural and historical reasons (Öniş, 2004). When CEECs such as Bulgaria and Romania, which do not have more stable democracies or a superior democratic culture in comparison to Turkey, were accepted as full members to the Union, the credibility of the EU as an unbiased organization was damaged and Turkey's motivation for further reforms to become a member of the European Union was hurt especially at the public level (Müftüler-Baç, 2000: 177).

After all, Turkey is going through a dynamic and consolidated process of modernization and democratization at an increased pace with an ambition to become a full member of the European Union. Although significant progress has been achieved, Turkey still has much political transformation to undertake before it can meet the standards of Europe. While the dispute with Armenians, conflict with Kurds and the problem with Cyprus have long been present in the Turkish political context, the possibility of Turkey's EU membership has made both their significance and resolution more severe (Göçek, 2008: 90). It is understandable that the Europeans might not want to transfer these century old problems into their own jurisdiction with Turkey's EU membership (Beriker and Eralp, 2005: 175). Turkey's bad human rights record as well as the protection of minorities in Turkey should be improved as a critical political condition (Türkmen, 2002). Turkey still has to further consolidate its democracy and improve its human rights record in order to meet the requirements of the Copenhagen political criteria (Baban and Keyman, 2008: 118). The political dimension of Turkey's integration in the European Union had always been problematic since the beginning of Turkey-EU relations and it continues to create barriers on Turkey's path to EU membership. 


\section{Security}

Transformation of the European Union in the areas of security and foreign policy has become increasingly vital for the Union's future to triumph as a powerful global actor in world affairs at the age of globalization. Turkey which has the second largest armed forces in the North Atlantic Treaty Organization (NATO) is therefore a valuable asset to Europeans if they seek to become a global actor with an active defense strategy. Besides its military capabilities, Turkey's geopolitical position is critically important, linking Europe with the Balkans, the Middle East and Central Asia. Consequently, Turkey stands at the crossroads of important energy, transportation and community networks and it plays a key role in balancing powers in the region. In addition to an enhanced military power, Turkish accession would increase the credibility of the EU as a foreign policy actor in the global arena (Emerson and Tocci, 2004: 8).

The Turkish military consists of 1,042,700 troops and it is larger than the military of any EU member state. Turkey is followed by France's 779,450 troops and Germany's 683,150 troops. Data indicates that larger European states have larger militaries, at the same time wealthier states tend to look after more troops. In the second group, Greece has the largest military; whereas more populated countries such as Poland and Romania have relatively smaller militaries. Latvia has the smallest military which consists of 22,750 troops. From this picture, one can understand that Turkey has important military power and spends more resources for its security, compared to the European standards, considering that only wealthy European states with higher populations have large militaries which remain significantly small in comparison to the Turkish military. Indeed, the data on military expenditure as a percentage of national GDP confirms the suggestions above.

Turkey allocates $5.3 \%$ of its GDP to military expenses, notably higher than the European Union average of $1.7 \%$. In the first group, France and the UK spend the most on their military by allocating $2.6 \%$ and $2.4 \%$ of their GDP respectively, while Spain only allocates $1.2 \%$. In the second group, Greece gets close to Turkey with $4.3 \%$ of GDP allocation whereas CEECs spend below $2 \%$ of their GDPs, except Bulgaria which allocated $2.6 \%$ of GDP on military spending. On the contrary, when the budgets of European militaries are evaluated, all countries in the first group except Spain seem to have a larger military budget than Turkey's. This is simply because these more developed economies have higher GDPs when compared to Turkey thus they can allocate more resources as a lower percentage of their GDP. While the budget of Turkish military is $\$ 30.936$ billion, the United Kingdom spends $\$ 57.67$ billion on its military. Nevertheless, this does not change the fact that military power is a priority for Turkey considering the size and the allocation of resources on military expenditure. Among the EU members in the second group, none of them have a military budget comparable to Turkey's size. All CEECs except Romania have military budgets below $\$ 1$ billion. Finally, the total budget allocated for national militaries of the European Union member states reaches \$257.467 billion.

There is a strong relationship between the quality of Turkey's integration process into the EU and the quality of the Europeans' security feeling (Oğuzlu, 2003). Turkey became a member of NATO in 1952 whereas France, the United Kingdom and Italy were among the founders of the North Atlantic Treaty Organization together with the United States in 1949. Although France quit full participation in NATO in 1966, it returned as an equal member in 2009. Germany joined NATO a few years after Turkey did, and Spain joined NATO in 1982. In the second group, Greece joined NATO at the same time with Turkey in 1952; Poland in 1999, while the remainder of the states have joined NATO in 
2004 when they became members of the EU. Indeed, all the CEECs with the exception of Yugoslavia (including today's Slovenia) were participants in the Warsaw Pact, an alternative military alliance to NATO created under the leadership of the Soviet Union in 1955. Turkey was an important ally to the founders of European Union from the perspective of history at a time when some among today's European Union members were enemies to the European integration.

Although it lost important bargaining power after the Cold War ended, Turkey's chances of being included within the EU have increased from a Western security perspective in the post-September 11 era (Oğuzlu, 2003: 295-297). Turkey’s strategic importance has become increasingly valuable for the European Union again, particularly as issues relating to Syria, Iran, Afghanistan and Iraq came forward in recent years (Heisbourg, 2003). Meanwhile, the European Union's failure to effectively respond to the conflicts in Kosovo and the Balkans in the 1990s turned the attention of Europeans towards larger geopolitical considerations in the region (Eralp, 2000: 52). From the European point of view, Turkey offers a number of specific potential assets for helping the EU address major security concerns such as weapons of mass destruction, global terrorism and illegal trafficking of drugs and people, and ranging from the concrete realities of location and logistics to matters of culture and ideology and the search for a harmony in the greater region rather than promoting a clash of civilizations (Emerson and Tocci, 2004: 4). The calculations of the potential benefits of Turkey's inclusion in the European Security and Defense Policy and the costs entailed by its exclusion is expected to have an enormous impact on the EU's policies towards Turkey (Müftüler-Baç, 2000: 489). After all, the proposal of a privileged partnership for Turkey is against the main EU foreign policy goal of building up its soft power beyond the Union's current borders in order to become a global actor.

From a geostrategic perspective, Turkey is geographically located at the center of Europe, the Middle East, the Eastern Mediterranean, the Balkans, the Caucasus and the Eurasian regions. Turkey is a key regional actor and it controls the strategically important straits which connect the Black Sea to the Mediterranean. Moreover, the countries surrounding Turkey supply $60 \%$ of the natural gas and petroleum demand of Europe, thus the role of Turkey is crucial in terms of providing stability in the regions including the Eastern Mediterranean, the Middle East and the Caucasus (Şen, 2004: 5). Oil and gas pipelines from Iraq, Iran, Azerbaijan and Russia make Turkey an energy hub for a Europe dependent on external energy reserves. It is ironic that Cyprus is forcing the Union to block the opening of the Energy chapter in the accession negotiations while Turkey has the potential to become a key EU energy partner if the EU is ready to commit funding for new projects and consistency to its relationships with Turkey.

Turkey's EU accession stands to be of comparable importance for the EU's emerging foreign and security policy to the 2004 enlargement of the ten new member states put together, if not greater (Derviş et al., 2004: 63). However, it would be unrealistic to expect that the EU would accept that Turkey would be treated equally with the most influential members at the decision-making process in European Security and Defense Policy (ESDP). However, it is critically necessary to formulate a design to include Turkey at the decision-making stage because Turkey seems determined to demand autonomous decision capacity in order to participate in ESDP. If the EU can devise such a formula there is much to win from cooperation for both sides (Houben and Tocci, 2001: 7-11). Turkey and the European Union have to realize that their interests in the Middle East are indeed highly convergent: Stability. 
Nevertheless, there are also issues of concern against Turkey's membership from the EU perspective. First of all, if Turkey becomes a part of Europe, so will the problems of the Middle East. One of the most important challenges faced by the Europeans with Turkish integration concerns the ability of the Union to control its external borders in a geography which it has not encountered before (Emerson and Tocci, 2004: 8). The European Union will gain an undeniably important strategic ally in security affairs; however it will also gain important problems considering that the EU will be neighbors with Iraq, Iran and Syria, often thought of by Europeans as fundamentalist Islamic threats to the West. Therefore, it is understandable if Europeans would not want to move their borders next to the nuclear threat of Iran or the chaotic regime in Iraq.

Finally, the fact that Turkey has traditionally been perceived as more of an ally with the United States rather than with Europe will continue to create problems in foreign policy coordination between Turkey and the EU. It is for sure that the Europeans will not want to have "an American spy" in their common foreign and security decision making levels; on the other hand the United States would not want to decrease the level of cooperation with Turkey at the expense of Turkey's harmonization of foreign policy with an emerging global actor such as the European Union. Moreover, the transatlantic alliance and the relations between NATO, the European Union and the United States need to be carefully revised if Turkey is to become a full member to the European Union (Mason and Penksa, 2003). After all, Turkey is a bridge between the Eastern and the Western worlds, with an important military power and extensive experience in the political affairs of the geopolitically critical regions of the Middle East, the Balkans, Caucasia and even Central Asia; therefore it will be an important asset for the EU to enhance its credibility as well as being a diplomatic, political, military and soft power in the region that would become a powerful actor in the international sphere.

\section{Social}

Turkey's integration in the European Union goes beyond demographic, economic, political or security factors: Turkey's accession to the EU is also about integration of two culturally distinct societies. Religious difference has always been an issue between Turkey and Europe from a socio-historical perspective, and the cultural difference was frequently pointed out by mainly right wing European politicians (Keyder, 2006: 72-79). The EU is perceived to be a "Christian Club" and the recent Christian Democrat governments in the European states amplified these arguments by proposing a privileged partnership to Turkey instead of equal membership. Christianity has long been an important component of the European identity since the Middle Ages. Even if it is not a pre-condition of accession to the EU according to the Copenhagen Criteria, religion is still a critical determinant of Europeanness at the social level today. Valéry Giscard d'Estaing, former French President (1974-1981) admitted his fear that Turkey's EU membership would be 'the end of Europe' (BBC News, 8 November, 2002). Although the former French President aimed to highlight the socio-historic differences between the two sides, this approach discriminates against Turkey on cultural and religious grounds, which is contradictory to the Treaties of the European Union, and therefore cannot be a part to the rational membership conditionality of the EU.

Indeed, Giscard d'Estaing is the first person to pronounce 'privileged partnership' (une relation privilégiée) for Turkey with the European Union in an interview given to the French journal Géopolitique in 2000 (Lannes, 2000). Today's President of France Nicholas Sarkozy has openly expressed his opposition to Turkey's full EU membership due to cultural as well as geographical grounds, although he has been cautious in mentioning religious differences in order to avoid fueling 
the problems France has been experiencing with its Muslim minorities in recent years. Indeed, there is a substantial Muslim immigrant population living in many parts of Europe, but none of the states included in this study has a Muslim majority. Even though the prospective membership of Bosnia and Herzegovina to the EU may change this fact before the negotiations with Turkey comes to an end, the significance of Turkey's geostrategic position and scale of population is not comparable to Bosnia. Nevertheless, when shaping cultural relationships with Turkey, it is important for the Europeans to acknowledge that Islam is among European religions today, and therefore it must be recognized not as an outsider or a threat to European identity but rather a domestic and minority European religion which is already an integral part of the European identity (Karlsson, 2004).

Considering the religious composition of the population of EU member states, Roman Catholics are the largest group in the European Union, followed by Protestants, Orthodox, Evangelicals and Anglican Protestants. In the first group of EU member states, Germany has the smallest religious majority of $35.7 \%$ that can be associated with a single denomination, which suggests that it has high religious diversity. In fact, there is a difference between a culturally religious society with little religious diversity such as Spain, and a diverse society housing small yet intensely religious groups such as Germany. One must not overlook the fact that the idea of privileged partnership by a group was originally proposed by German Christian Democrats. On the contrary, 99\% of the Spanish society consists of Roman Catholics but Spain still supports Turkey. In the second group, Latvia and Estonia have the highest religious diversity rates while more than $90 \%$ of Greek people are Orthodox. The latest countries to join the EU in 2004 have various different religious backgrounds and belong to different denominations within Christianity so there is not a visible pattern in European enlargement. Although Roman Catholic societies may seem to have less religious diversity, Latvia has the highest level of diversity yet a majority of Roman Catholics. Finally, Turkey has a majority religion of $80 \%$ Sunni Muslims, which is relatively high with still some degree of religious diversity at least on paper (Fox, 2008). According to the 'Religion, Secularism and the Veil in Daily Life Survey' report presented in 2007 by Konda, a leading research and consultancy, 99\% of the Turkish population are Muslim, among which $82 \%$ are Sunni-Hanefi and $5.73 \%$ belong to the Alevi-Shi denomination. Although the Alevi Muslims represent the largest religious minority group in Turkey, they are not officially recognized by the State Department of Religious Affairs and are referred to as simply Muslims, belonging to the same large group of Sunni Muslims. Therefore, one cannot speak of religious pluralism in practice in Turkey at least until the 'Cemevleri,' worship places for Alevi Muslims, are officially recognized.

The level of religiosity is as important as the religion itself. Although personal beliefs are always hard to measure, results from the World Values Survey suggest that $82.6 \%$ of Turkish people label themselves as religious, while Italy is the only country with $88 \%$ religiosity which is higher than Turkey in the first group. Only $42.9 \%$ of Germans tag themselves as religious; Poland and Romania appear to have the most religious societies with $94.6 \%$ and $93.4 \%$ respectively. When all religious indicators are combined, one can conclude that Germany at large is the least religious country with a high degree of religious diversity which has a majority of $35.7 \%$ Evangelical Christians. On the other hand, the Polish are the most religious society dominated by $92.2 \%$ Roman Catholics; but these religion indicators are unsuccessful in explaining the political motivations behind the proposal of a privileged partnership to Turkey.

Education is a critical tool for the modernization of the Turkish society to reach the European standards, therefore it is an important aspect of Turkey's integration in the EU. The data on education indicates that the average school expectancy from a Turkish citizen is 12.5 years, compared to the 17.2 years of 
average European school expectancy. Therefore, there is a significant gap between Turkish society's level of education and the Europeans'. Furthermore, this is not the average schooling of Turkish population but the expectation from students who are going to school today, which means the actual level of education in Turkey is more likely to be even lower. In the first group of EU states, school expectancy is around 17 years while in the second group Poland, Estonia, Latvia and Lithuania have the highest expectancy around 18 years which means that the relatively less developed states that entered the EU in 2004 have higher expectations for schooling in order to close the gap with the more developed parts of Europe.

On the other hand, Romania and Bulgaria have school expectancy below 16 years and Cyprus at 14.8 years which is as near as it gets to school expectancy in Turkey. Nevertheless, data also indicates that Cyprus allocated the highest GDP portion, 7.02\%, to education compared to other European states. The average GDP allocation in the EU member countries is $5.04 \%$ while this percentage is only 2.86 in Turkey. In other words, Turkey allocates the minimum percentage of GDP to education among the states included in this study. While the Turkish government spends 21,011 million Euros on education, Germany spends 99,395 million Euros which explains why Germany has more skilled labor, better economic credentials and political influence within the EU. Furthermore, Turkey has a very young population which means there are more students in Turkey than in Germany, and Turkey still spends one fifth of what Germany spends on a predictably larger number of students. Moreover, France and the UK also spend more than 90 billion Euros on education while even Poland with its GDP lower than Turkey and almost half of Turkey's population spends more than Turkey on educating its citizens. Finally, Turkey clearly lags behind in terms of education when compared to the CEECs which allocate higher percentage of their GDP's to educating their future generations (Derviş et al., 2004: 66-67).

Women rights and gender relations determine an important aspect of social norms and the gender gap score indicates the inequality between male and females in a society. According to the World Economic Forum 'The Global Gender Gap Report 2009' overall scores, Turkey's score of 0.5828 is severely lower than any other state included in this study. In the first group, Germany stands out with 7.449 while Italy has the lowest score which is 0.6798 . In the second group, Latvia has the highest score which is 0.7416 and all other CEECs have relatively high scores above 0.7 except Romania. Greece, often referred to as having a similar societal structure to Turkey, has a score of 0.7345 . Therefore, one may conclude that Turkey has to resolve problems with gender relations in society before it can even get close to European social norms.

When the data on health and the standard of living is evaluated, Turkey lags behind the European standards for one more time. Unfortunately, Turkey's infant mortality rate suggests that 16 out of 1000 live births die in the first years of their lives and this is drastically below the EU standards. The average infant mortality rate in European Union member states is 4.7; Germany and Spain in the first group in addition to Greece in the second group have infant mortality of 3.5 per 1000 live births (2008). This ratio goes up to 11 and 8.6 in the latest European Union members of Romania and Bulgaria respectively. Nevertheless, having the highest infant mortality rate, the value of life in Turkey is still relatively low even if there has been a significant improvement of $50 \%$ decline in this specific indicator during the last decade.

Environment is another important subject in the European agenda for Turkey's accession. Greenhouse Gas Emissions can provide an idea of how much importance is given to the environment in different countries. The European average score is 90.7, while Germany has the lowest gas emission with 77.6 
and Spain has the highest score with 152.6 in the first group. On the contrary, CEECs in the second group have very low greenhouse gas emission scores all at 50s, Latvia having the lowest score of 46.6. Unfortunately, Turkey has a score of 219.1, which is approximately two and a half times of the European average, and more than four times the average of the CEECs.

Although Turkey's European Union candidacy since 1999 has stimulated political and legal reforms, it also intensified the "Europeanization" process in Turkey. Indeed, Turkey's Europeanization is greatly motivated by its prospect of full membership in the Union (Müftüler-Baç, 2005: 16). However, various indicators confirm that there are critical differences between the Turkish and European societies and it will take time for these sharp social differences to fade away even if Turkey chooses to accept European cultural norms. On the contrary, it would be wrong to state that Christian Europe has a homogenous culture and Turkey's difference should not be seen only as a liability, but as a strength for diversity and multiculturalism in Europe (Kirişci, 2008). Indeed, Turkey's full membership in the Union would have an important transformative impact on the structures of EU in terms of determining European identity and post national forms of a European public sphere in globalized world. Today, one of the most important debates in Europe is the construction of a multicultural cosmopolitan European identity. If Turkey became a member of the EU, Europeans would be able to defy all the accusations suggesting that the EU is a Christian Club. Basically, even the prospects of Turkey's membership require Europe to rethink its borders and identity (Baban and Keyman, 2008: 110).

\section{PUBLIC OPINIONS AND CONCLUDING REMARKS}

Public opinion in Europe is against further enlargement of the Union. Although $43 \%$ of Europeans support further enlargement, $46 \%$ are against it (European Commission, 2009). In the first group, Germans are the most cautious of further enlargement as $66 \%$ of the society does not want to see newcomers and only a $27 \%$ favors a wider EU. Spain is the only country in the first group which supports further enlargement. However, in the second group all EU members with the exception of Greece clearly support enlargement of the EU. Highest support comes from Romania and Poland where over $65 \%$ is for enlargement and only around $15 \%$ is against it. Therefore, there is an obvious trend in the CEECs to support further new members joining the EU. Besides the fact that they may feel marginalized as newcomers, these countries are also relatively poor and therefore they might support other poor countries' EU membership to create a competitive advantage for economic purposes. On the other hand, richer countries such as Germany and France would not want to see 'another poor country' joining the EU due to economic interests. Finally, a smaller Union is easier to control and influence, according to converging national interests than is an EU with more new members.

When the Europeans are asked specifically about the accession of Turkey, $61 \%$ believe that cultural differences between the two societies are too high; $66 \%$ have a fear of possible immigration from Turkey, 77\% point out Turkey's troubled economy and a towering $85 \%$ believe that Turkey has problems with human rights, while only $33 \%$ of Europeans think that membership of Turkey can help Europe enhance its security and defense (European Commission, 2006). Terrorism in Turkey also rose as a major concern for the Europeans according to the latest Eurobarometer SD 75 (European Commission, 2011). On the other hand, Turkey's accession might symbolize for the southern states a different meaning to counterbalance northern enlargement in order for the Union to have more of a Mediterranean orientation in power balance. This argument is supported by public opinion in the Southern European countries which show relatively higher support for Turkey's membership compared to Northern European countries (Keyder, 2006: 79). Although the public opinion in all EU 
member states included in this study unanimously indicate that there are serious problems regarding Turkey's economy and human rights, Germans in the first group and Greeks in the second group appeared to be the most unsympathetic to Turkey's EU membership. The United Kingdom with 68\% trust supports Turkey on security matters. Ironically, only 64\% of Turks responded that Turkey has the potential to enhance Europe's security (European Commission, 2006).

The general feeling in the Turkish public towards the European Union's privileged partnership proposal is that such a partnership is biased to grant greater benefits to the EU than it would grant to Turkey because these privileges would bring only marginal economic and security benefits to a country that is already a part of the Customs Union and NATO. Europeans often overlook the fact that a privileged partnership already exists between Europe and Turkey (Gros, 2004), or that in embracing the 'privileged partnership' language, they are possibly looking for a sophisticated way to say that they prefer the status quo. According to the recent data from Eurobarometer SD 75 (European Commission, 2011), there is a slight majority in Turkey that support EU membership, as $41 \%$ of respondents think that membership would be a good thing for Turkey whereas $29 \%$ think that it would be bad for their country. Forty-eight percent say that EU membership would benefit Turkey while the opposite opinion has grown during the last year and reached 38\%. Meanwhile, there has been a significant decline of $12 \%$ for the optimism in Turkey. After all, distrust in EU institutions continues to prevail as the highest in Turkey with $63 \%$ of Turkish people not trusting the EU.

Turkey's initial attitude is highly negative to any form of partnership with the European Union because, after all the progress made and all the transformations achieved by the Turkish state on the way to European Union membership, any scenario short of full membership is not expected to be welcome in Turkey (Müftüler-Baç, 2000: 500). The end result aimed at by negotiations with Turkey must be full membership and no other objective can meet the challenge that Europe and Turkey have been facing together (Derviş et al., 2004: 109). After all, the European Union can tolerate Poland's inefficient agriculture sector, Bulgaria or Romania's weak democratic culture, Cyprus's geographical position next to the troubled Middle East or Greece's distressed economy. If the Europeans were to insist on the objectivity of their membership conditionality then maybe the EU has the capacity to actually tolerate Turkey as a full member rather than a privileged partner.

However, a general skepticism towards a Muslim country that has an entirely different social background as well as historical bad memories may cause a negative feeling towards Turkey's full membership at the public level in Europe. Turkey's poor economy, weak democratic credentials, unresolved Cyprus question in addition to Armenian and Kurdish disputes and issues of disrespect for human rights and minorities do not help Turkey gain support from the Europeans either. On the other hand, no one could deny that Turkey's geostrategic position and military power is of great significance. Indeed, the military appears to be an important asset of Turkey regarding its relations with the European Union. Membership of Turkey could have a considerable impact on the EU's security and defense policies as well as its foreign policy objectives and the presence of the Turkish military could become an important asset for Europeans to achieve Common Foreign and Security Policy goals.

After all, Turkey is a big country with a large and relatively poor population which has a cultural and religious background that differs from the existing EU member states. Turkey's young population is expected to grow in the coming years while the EU's population is expected to decline and the Europeans are facing the problem of aging population. Although supporters of Turkish accession 
propose that Turkey's dynamic and large young population will be an asset for the EU, they overlook the fact that Turkish population is unutilized, a relatively high proportion of the young people in Turkey are unemployed, a great share of Turkey's labor force works in agriculture, Turkish labor force is unskilled, and is significantly less productive yet drastically small compared to the size of Turkey's population in comparison to its European counterparts. From an economics perspective, Turkey is poor but its economy has a potential of high growth thanks to its young population which Turkey has been unsuccessful in educating and utilizing in the labor force. Besides, investments in Turkey are low compared to the European levels and this further blocks the potential of Turkish economy to maintain stability and experience a rapid growth to fill in the gap between Turkey and the EU.

Furthermore, education emerges as a crucial weakness of Turkey. In addition to the fact that Turkey's population is severely uneducated when compared to the Europeans, it is even more embarrassing for Turkey that it allocates the least percentage of its resources to education. In fact, Germans spend almost five times more money on education than Turkey does, and it is Turkey that has a larger young population and that seeks to close the education gap existing between the two sides. In other words, data suggests that the education gap between Turkey and the EU cannot possibly be narrowed unless government spending in Turkey prioritizes education and radically changes the allocation of resources for schooling. Turkey allocates a vast amount of its resources for military expenses, more than three times the European average to maintain the power and the prestige of its military. However, if Turkey aims to reach the European standards through sustainable transformation in economic and social spheres, it might be wise to consider allocating more funds to education rather than funding the armed forces above European standards. An uneducated labor force is unskilled and less productive, thus Turkey's young and large population will become a disadvantage for Turkey in its relations to the European Union, even though it has a potential to become an asset in theory.

In terms of economics, inflation is a problem which Turkey has managed to handle in a successful way in recent years. Nevertheless, Turkish economy is still unstable and the inflation rate is high when compared to the European economies, and Turkey needs to resolve this problem before it can fulfill the Copenhagen Criteria. Other than economic conditions, the membership conditionality stresses democracy, the rule of law, human rights and respect for and protection of minorities; the evaluation of indicators included in this research shows that they are still very problematic in Turkey. Indicators of democracy, political rights, civil liberties, gender relations, standard of living, government involvement in religion and protection of environment all unanimously suggest that Turkey cannot meet the European standards and even the standards of Central and Eastern European countries. Contrary to the common belief, Turkey is indeed backwards in all of these policy areas which set the basis for the European conditionality of Copenhagen Criteria, in comparison to the CEECs that qualified for the European Union membership in the last two rounds of enlargements.

In conclusion, results of this comparative study suggest that Europeans do not have to be biased against Turkey or impose double standards when proposing a privileged partnership to Turkey rather than full membership because Turkey is indeed different from current members of the EU according to a set of rational indicators. There are some differences among the EU members in separate groups especially in terms of economic development. Although the CEECs have a limited experience of democracy in their pasts, data suggests that their democratic credentials are stronger than the quality of Turkish democracy today. Turkey appears to lag behind the EU members in the second group more than they fall behind the EU members in the first group. Furthermore, data indicates that there are considerable efforts from the CEECs to catch up while Turkey's progress has been only partial. Finally, the CEECs 
have even better qualifications than members in the first group in parts of the social criteria, while Turkey is out of the European league.

Although it is clear from the European public opinion that the majority of Europeans do not want to see Turkey as a full member of the EU, this does not have to be based on irrational reactions relying on cultural or religious grounds. As this study points out, Turkey is indeed radically different from the established European Union states in the first group as well as the new EU members from Central and Eastern Europe in the second group on a number of objective indicators. Finally, this article does not evaluate the question of whether the Europeans led by the Christian Democrats are biased against Turkey's membership due to cultural or historic reasons, but it suggests solely that there are rational grounds other than irrational or sentimental factors for proposing Turkey for a privileged partnership from the European perspective. Even if it is true that Europeans are prejudiced against Turkey's accession, the results of this study indicate that Turkey is much behind the European standards especially in social and political conditionality, and therefore in fulfilling the Copenhagen Criteria to achieve full membership to the Union. Hence, before talking about European bias and historical prejudices, Turkey must ambitiously continue its transformation and undertake further reforms to become a full fledged democracy which would automatically render it also eligible for joining the European Union as a full member on equal grounds. On the contrary, if Turkey remains "unequal" to European member states as the empiric data suggests it is in various fields today, then the "unequal" European proposition of a privileged partnership is worth considering for Turkey. When the current progress of Turkey towards EU membership is acknowledged, by ignoring the offer of a privileged partnership Turkey would take the risk of abandoning its long European dream, while the EU must be ready for the consequences of losing an important ally with a key geo-strategic position which would basically harm both sides on a great scale in the $21^{\text {st }}$ Century's globalized world.

Today, at a point which Turkey has lost its momentum for further reforms, there are two possible outcomes in the future of Turkey-EU relations. Turkey should continue its transformation with an increased pace for closing the actual gap that exists between European and Turkish standards, without putting forward arguments for European bias or double standards, or should accept privileged partnership as a fair and viable solution as well as an end result of Turkey's long history of European integration.

\section{REFERENCES}

Airaudo, M., Bayar, F., Derviş, K., Gros, D., Işık, Y., and Öztrak, F. (2004). “Stabilizing Stabilization,” Centre for European Studies: EU - Turkey Working Papers, 7: 1-31.

Aybet, G. (2006). "Turkey and the EU after the First Years of Negotiations: Reconciling Internal and External Policy Challenges," Security Dialogue, 37(4): 529-549.

Aydın S. and Keyman F. (2004). "European Integration and Transformation of Turkish Society," Centre for European Studies: EU - Turkey Working Papers, 2: 1-50.

Baban. F. and Keyman, F. (2008). "Turkey and Post-national Europe: Challenges for the Cosmopolitan Political Community," European Journal of Social Theory, 11(1): 07-124. 
Bayar, F., Derviş, K., Gros, D., Iş1k, Y., and Öztrak, F. (2004). "Relative Income Growth and Convergence," Centre for European Studies: EU - Turkey Working Papers, 8: 1-18.

Beriker N. and Eralp, D.U. (2005). "Assessing the Conflict Resolution Potential of the EU: The Cyprus Conflict and Accession Negotiations," Security Dialogue, 36(2): 75-192.

Çarkoğlu, A. and Kirişci, K. (2003). "Perceptions of Greeks and Greek-Turkish Rapprochement by the Turkish Public,” in B. Rubin and A. Çarkoğlu (eds.), Greek-Turkish Relations in an Era of Détente: 117-153. London: Frank Cass.

Derviş, K., Emerson, M., Gros, D., and Ülgen, S. (2004). The European Transformation of Modern Turkey. Brussels: Centre for European Policy Studies.

Emerson, M. and Tocci, N. (2004). "Turkey as a Bridgehead and Spearhead: Integrating EU and Turkish Foreign Policy," Centre for European Studies: EU - Turkey Working Papers, 1: 1-35.

Eralp, A. (2000). “European Security and Turkey,” Private View, 8: 52-55.

Ersel, H. and Togan, S. (2005). "Macroeconomic Policies for Turkey's Accession to the EU," in B.M. Hoekman and S Togan (eds.), Turkey: Economic Reform and Accession to the European Union: 3-35. Washington DC: The International Bank for Reconstruction and Development / The World Bank.

Erzan, R. and Kirişci, K. (2004). "Turkish Immigrants: Their Integration within the EU and Migration to Turkey," Turkish Policy Quarterly, 3(3): 61-68.

Erzan, R., Kuzubaş, U., and Yıldız, N. (2004). "Growth and Immigration Scenarios for Turkey and the EU,” Centre for European Studies: EU - Turkey Working Papers, 13: 1-13.

European Commission. (2006). Eurobarometer SD 66. Available [on line] at: http://ec.europa.eu/public_opinion/archives/eb/eb66/eb66_en.pdf

------, (2009). Eurobarometer SD 71. Available [on line] at:

http://ec.europa.eu/public_opinion/archives/eb/eb71/eb71_std_part1.pdf

-----, (2011). Eurobarometer SD 75. Available [on line] at:

http://ec.europa.eu/public_opinion/archives/eb/eb75/eb75_en.pdf

Francois, J. (2005). "Accession of Turkey to the European Union: Market Access and Regulatory Issues," in B.M. Hoekman and S Togan (eds.), Turkey: Economic Reform and Accession to the European Union: 123-145. Washington DC: The International Bank for Reconstruction and Development / The World Bank.

Freedom House, (2009). Freedom in the World Report 2009 Edition. Available [on line] at: http://www.freedomhouse.org

Fox, J. (2008). A World Survey of Religion and the State. Cambridge: Cambridge University Press.

Göçek, F.M. (2008). “Through a Glass Darkly: Consequences of a Politicized Past in Contemporary Turkey," The ANNALS of the American Academy of Political and Social Science, 617: 88-106. 
Gros, D. (2004). "Financial Aspects of Central Bank Independence and Price Stability: The Case of Turkey," Centre for European Studies: EU - Turkey Working Papers, 12: 1-12.

Güney. A. and Karatekelioğlu, P. (2005). "Turkey's EU Candidacy and Civil-Military Relations: Challenges and Prospects," Armed Forces and Society, 31(3): 439-462.

Heisbourg, F. (2003). “Turkey’s Strategic Future,” European Security Forum - Working Papers, 13: $1-48$.

Houben, M. and Tocci, N. (2001). “Accommodating Turkey in ESDP," Centre for European Studies: Policy Brief, 5: 1-11.

Karlsson, I. (2004). "Turkey's Cultural and Religious Heritage: An Asset to the European Union," Turkish Policy Quarterly, 3(3): 1-6.

Keyder, Ç. (2006). "Moving in from the Margins? Turkey in Europe," Diogenes, 53(2): 72-81.

Keyman, F. and Öniş, Z. (2004). "Helsinki, Copenhagen and Beyond: Challenges to the New Europe and the Turkish State," in M Uğur and N Canefe, (eds.), Turkey and European Integration: Accession Prospects and Issues: 1-31. London: Routledge.

Kirişci, K. (2008). “Turkey too Big, too Poor and too Different: Asset or Liability?," in C. Timmerman, S. Mels, and D. Rochtus (eds.), European and Turkish Voices in Favor and Against Turkish Accession to the European Union: 127-138. Brussels: Peilang.

KONDA Research and Consultancy, (2007). Religion, Secularism and the Veil in Daily Life Survey. Available [on line] at: http://www.konda.com.tr/en/reports.php?tb=2

Lannes, S. (2000). "Entretien avec le Président Valéry Giscard d'Estaing: l'Europe met la Turquie en porte-à-faux," Géopolitique: 69: 5-8.

Mason, W.L. and Penksa, S.E. (2003). "EU Security Cooperation and the Transatlantic Relationship," Cooperation and Conflict, 38(3): 255-280.

Missiroli, A. (2002). "EU - NATO Cooperation in Crisis Management: No Turkish Delight for CFSP," Security Dialogue, 33(1): 9-26.

Müftüler-Baç, M. (2000). “Turkey's Role in the EU's Security and Foreign Policies," Security Dialogue, 31(4): 489-502.

------, (2005). “Turkey's Political Reforms and the Impact of the European Union," South European Society and Politics, 10(1): 16-30.

Narbone, L. and Tocci, N. (2007). "Running around in Circles? The Cyclical Relationship between Turkey and the European Union," Journal of Southern Europe and the Balkans, 9(3): 233-245.

Oğuzlu, H.T. (2003). “An Analysis of Turkey’s Prospect Membership in the European Union from a Security Perspective," Security Dialogue, 34(3): 285-299. 
Öniş, Z. (2004). "Diverse but Converging Paths to European Union Membership: Poland and Turkey in Comparative Perspective," East European Politics and Societies, 18(3): 481-512.

Özler, Ş. and Taymaz, E. (2005). "Labor Market Policies and EU Accession: Problems and Prospects for Turkey," in B.M. Hoekman and S. Togan (eds.), Turkey: Economic Reform and Accession to the European Union: 223-260. Washington DC: The International Bank for Reconstruction and Development / The World Bank.

Rumford, C. (2003). "Resisting Globalization? Turkey - EU Relations and Human and Political Rights in the Context of Cosmopolitan Democratization," International Sociology, 18(2): 379-394.

Schimelfennig, F. and Selemeier, U. (2002). "Theorizing EU Enlargement: Research Focus, Hypotheses, and the State of Research," Journal of European Public Policy, 9(4): 500-528.

Şen, F. (2004). “The Impact of a Turkish Entry in the EU,” Turkish Policy Quarterly, 3(3): 1-6.

The Economist, (2008). The Economist Intelligence Unit's Index of Democracy 2008. Available [on line] at: http://graphics.eiu.com/PDF/Democracy\%20Index\%202008.pdf

Türkmen, F. (2002). “The Human Rights Factor in Turkey - EU Relations,” Turkish Policy Quarterly, 1(3): 1-9.

TUIK, (2011). "Household Labor Force Survey Results," Turkish Statistical Institute Report No: 214, published on October 17, 2011.

Ülgen, S. and Zahariadis, Y. (2004). "The Future of Turkey - EU Trade Relations," Centre for European Studies: EU - Turkey Working Papers, 5: 1-32.

Vatanen, A. (2006). "A Youthful Turkey: An Asset or a Burden for the EU," Turkish Policy Quarterly, 5(1): $19-25$.

Winkler, N. (2005). "Leaving the Rollercoaster: Turkey, Stability and the EU," Turkish Policy Quarterly, 4(3): 1-10.

World Economic Forum, (2009). The Global Gender Gap Record. Available [on line] at: http://www.weforum.org/pdf/gendergap/report2009.pdf

Y1lmaz, B. (2002). “Turkey's Relations with the European Union: Economic Integration between EU and Turkey," Turkish Policy Quarterly, 1(3): 107-116.

Y1lmaz, H. (2004). Euroskepticism in Turkey: Manifestations at the Elite and Popular Levels. İstanbul: Boğaziçi University Press.

-----, (2007). "Turkish Identity on the Road to the EU: Basic Elements of French and German Oppositional Discourses," Journal of Southern Europe and the Balkans, 9(3): 293-305. 
APPENDIX A

\begin{tabular}{|c|c|c|c|c|c|c|c|c|c|c|c|c|c|c|c|c|c|c|c|c|c|c|c|c|}
\hline & $\begin{array}{l}\text { N } \\
\text { ב }\end{array}$ & & $\begin{array}{l}\text { జू } \\
\text { స్ } \\
\text { స్ }\end{array}$ & ఫ్లి & -1 & $\begin{array}{l}\text { స్ } \\
\text { స్ } \\
\text { gू } \\
\text { gे }\end{array}$ & 융 & 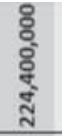 & 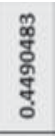 & ๙ิ & 号 & & 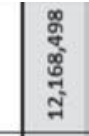 & ‡ & $\overline{7}$ & $\begin{array}{l}\text { \% } \\
\text { ई }\end{array}$ & \&్ల & $\ddot{\gamma}$ & $\frac{4}{6}$ & 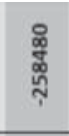 & รี & ః & 근 & H \\
\hline \multirow{8}{*}{ 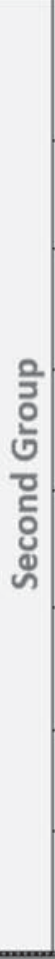 } & 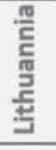 & & $\begin{array}{l}\text { ષ્సે } \\
\text { ڤે }\end{array}$ & $\cong$ & 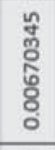 & $\begin{array}{l}\tilde{\omega} \\
\text { o. } \\
\text { హ. } \\
\text { ळ. }\end{array}$ & 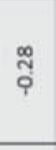 & \begin{tabular}{l}
8 \\
\& \\
\multirow{0}{0}{} \\
- \\
-1
\end{tabular} & 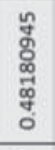 & $\begin{array}{l}\hat{6} \\
\stackrel{+}{+}\end{array}$ & m & & $\begin{array}{l}\text { స్. } \\
\text { ఏ్ర }\end{array}$ & ฉี & $\stackrel{0}{\oplus}$ & 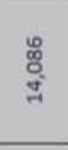 & กี & $\hat{p}$ & 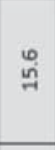 & ڤ్ํำ & 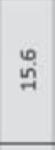 & ถึ & $\underset{j}{0}$ & F \\
\hline & 营 & & 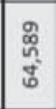 & $\cong$ & 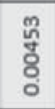 & $\begin{array}{l}\text { तू } \\
\text { ]్ } \\
\text { స్ }\end{array}$ & t] & 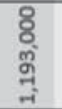 & $\begin{array}{l}\hat{\text { ก}} \\
\text { ज్ } \\
0\end{array}$ & $\begin{array}{l}\infty \\
\text { ָె } \\
\text {. }\end{array}$ & $\vec{g}$ & & 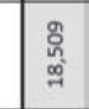 & 3 & $\stackrel{\infty}{\dddot{0}}$ & $\begin{array}{l}\text { ఫ్ } \\
\text { ఫ్ }\end{array}$ & $\vec{~}$ & $\overline{7}$ & $\stackrel{n}{g}$ & ๕̊ & జे & $\hat{g}$ & $\stackrel{m}{\tilde{z}}$ & $\stackrel{m}{m}$ \\
\hline & 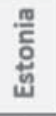 & & $\begin{array}{l}\text { స్ } \\
\text { ูু }\end{array}$ & $\rightarrow$ & $\begin{array}{l}\text { : } \\
\text { ఫ్ర } \\
\text { ర్ }\end{array}$ & 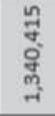 & $\stackrel{\text { : }}{\circ}$ & 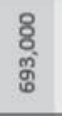 & 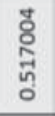 & ถึ & g & & $\begin{array}{l}\stackrel{\infty}{\infty} \\
\stackrel{\varpi}{\nexists ٍ ~}\end{array}$ & 5 & $\hat{\dddot{m}}$ & 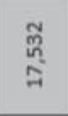 & ڤั & $\hat{i}$ & $\stackrel{\infty}{+}$ & ఫ్ ช్ & $\overrightarrow{\tilde{N}}$ & : & Эี & ชี \\
\hline & 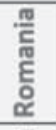 & & 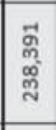 & in & $\begin{array}{l}\text { J } \\
\text { ơ } \\
\text { ○े }\end{array}$ & 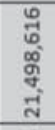 & $\stackrel{n}{\circ}$ & 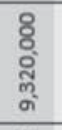 & 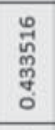 & خె & $\hat{\tilde{m}}$ & & $\begin{array}{l}m \\
\stackrel{m}{m} \\
\text { g }\end{array}$ & - & $\infty$ & 일 & $\frac{m}{y}$ & นึ & $\stackrel{\bullet}{\dddot{g}}$ & $\begin{array}{l}\text { : } \\
\text { స్ }\end{array}$ & ò & $\stackrel{m}{\sigma}$ & $\cong$ & $\stackrel{\bullet}{\text { iे }}$ \\
\hline & 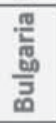 & & $\begin{array}{l}\text { नี } \\
\text { 하 }\end{array}$ & $\approx$ & $\begin{array}{l}\text { స్ } \\
\text { : } \\
\text {. }\end{array}$ & $\begin{array}{l}\text { ज. } \\
0 \\
0 \\
0 \\
0 \\
0\end{array}$ & 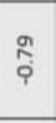 & $\begin{array}{l}8 \\
8 \\
0 \\
6 \\
i \\
1\end{array}$ & $\begin{array}{l}\text { on } \\
\text { ỗ } \\
\text { } \\
0\end{array}$ & 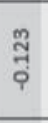 & $\stackrel{j}{7}$ & & 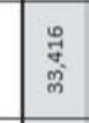 & \% & ฟे & $\begin{array}{l}\overrightarrow{0} \\
\hat{\omega} \\
\overrightarrow{6}\end{array}$ & ભ & $\stackrel{\infty}{\sim}$ & $\vec{J}$ & $\begin{array}{l}\text { ̊̊ } \\
\text { क़̣ }\end{array}$ & $\tilde{~}$ & 总 & $\stackrel{\infty}{\sim}$ & $\stackrel{n}{2}$ \\
\hline & 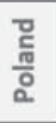 & & 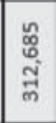 & $\vec{I}$ & 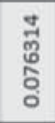 & $\begin{array}{l}0 \\
0 \\
\infty \\
\infty \\
\infty \\
\infty \\
\infty \\
\infty\end{array}$ & $\begin{array}{l}\text { "̊ } \\
\stackrel{0}{0}\end{array}$ & $\begin{array}{l}8 \\
8 \\
0 \\
0 \\
\end{array}$ & 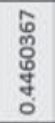 & $\begin{array}{l}\text { ఫे } \\
\text { ğ }\end{array}$ & $\stackrel{9}{\frac{9}{m}}$ & & 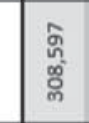 & $\cong$ & $\mp$ & 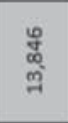 & ભ & 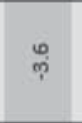 & $\stackrel{\sim}{\tilde{\sigma}}$ & ڤ్రి & :̊ํ․ & జ్ర & $\underset{\infty}{\infty}$ & + \\
\hline & 紊 & & 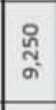 & ะ & $\begin{array}{l}\text { \% } \\
\text { ठี } \\
\text { : }\end{array}$ & 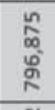 & นี้ & $\begin{array}{l}8 \\
\\
\text { ¿ }\end{array}$ & 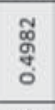 & $\stackrel{\Xi}{\exists}$ & 点 & & 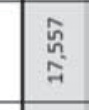 & $\overrightarrow{0}$ & $\hat{\phi}$ & $\begin{array}{l}\stackrel{\text { a }}{\text { ja }} \\
\text { }\end{array}$ & \& & g & $\underset{\not j}{\not j}$ & 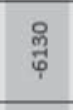 & $\hat{g}$ & 吕 & ชี & ชี \\
\hline & 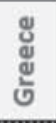 & & $\begin{array}{l}\text { 여 } \\
\text { ने }\end{array}$ & $m$ & 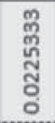 & 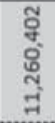 & $\stackrel{m}{0}$ & $\begin{array}{l}8 \\
\text { ठ̀. } \\
\text { o. } \\
\text { f }\end{array}$ & 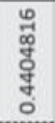 & $\underset{\infty}{\vec{\infty}}$ & $\stackrel{\infty}{j}$ & & $\begin{array}{l}\text { đू } \\
\text { ờ }\end{array}$ & $\sim$ & 7 & 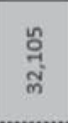 & \&̊․ & $\hat{\imath}$ & สี & $\begin{array}{l}\stackrel{\%}{\%} \\
\text { \%̆ }\end{array}$ & Ф્ન & ड़ & $\hat{\sigma}$ & $\stackrel{m}{-1}$ \\
\hline \multirow{6}{*}{$\begin{array}{l}\text { 을 } \\
\text { 은 } \\
\text { 는 } \\
\frac{2}{1}\end{array}$} & $\begin{array}{l}\text { d) } \\
\frac{\vec{y}}{3} \\
\stackrel{2}{2}\end{array}$ & & 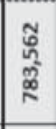 & $\underset{\sigma}{0}$ & 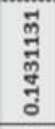 & 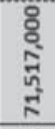 & $\vec{y}$ & 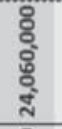 & 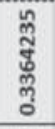 & 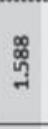 & $\hat{i}$ & & 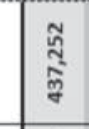 & \%̊․ & ڤ్ & 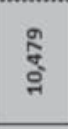 & gี & $\pi$ & జ్లి & 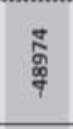 & 乡ે & \% & $\stackrel{\sim}{\dot{m}}$ & \% \\
\hline & $\begin{array}{l}\text { 등 } \\
\text { 号 }\end{array}$ & & 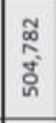 & $\stackrel{్}{~}$ & 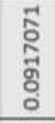 & 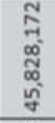 & oิ & 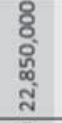 & 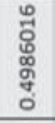 & 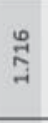 & $\overline{7}$ & & 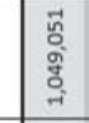 & $\underset{\infty}{\infty}$ & के & ज्ञ & ัँ & $\overrightarrow{7}$ & 今̊ & 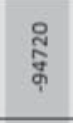 & $\vec{d}$ & 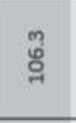 & 苛 & $\stackrel{m}{p}$ \\
\hline & 를 & & $\begin{array}{l}\text { స్ } \\
\text { స్ల }\end{array}$ & $\underset{0}{\infty}$ & $\begin{array}{l}\text { : } \\
\text { ఫี } \\
\text { శ్ }\end{array}$ & $\begin{array}{l}0 \\
0 \\
0 \\
\text { s. } \\
0 . \\
0 \\
0\end{array}$ & $\begin{array}{l}\text { n̊ } \\
\stackrel{0}{0}\end{array}$ & $\begin{array}{l}8 \\
\text { ]े } \\
\text { มี }\end{array}$ & 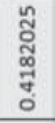 & 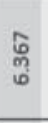 & $\stackrel{m}{g}$ & & 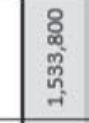 & $\stackrel{\leftrightarrow}{\underset{J}{J}}$ & दे & 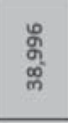 & $\stackrel{\infty}{\infty}$ & $\hat{\imath}$ & ڤ్ల & $\begin{array}{l}\stackrel{̊}{ఖ} \\
\underset{7}{7}\end{array}$ & 9 & กี & $\stackrel{m}{\infty}$ & $\stackrel{\infty}{0}$ \\
\hline & $\stackrel{ن}{3}$ & & $\begin{array}{l}\text { ळ్ } \\
\text { J゙๋ }\end{array}$ & กิ & $\begin{array}{l}\text { J } \\
\text { ग } \\
\text { సี } \\
0 \\
\end{array}$ & $\begin{array}{c}\text { s. } \\
\text { - } \\
0 \\
0 \\
0 \\
\end{array}$ & ณี & 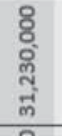 & 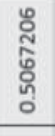 & $\underset{m}{\infty}$ & õ & & 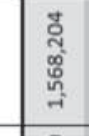 & & $\stackrel{0}{+}$ & 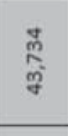 & ন & n & กี & 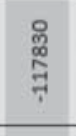 & j & ఝั & $\stackrel{9}{r}$ & $\stackrel{0}{\infty}$ \\
\hline & 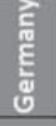 & & స్ & $\vec{\infty}$ & 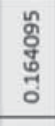 & 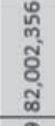 & $\begin{array}{l}\text { no } \\
\text { ô }\end{array}$ & $\begin{array}{l}8 \\
8 \\
8 \\
0 \\
o \\
\text { g. }\end{array}$ & 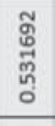 & $\begin{array}{l}\overrightarrow{0} \\
0 \\
\stackrel{0}{0}\end{array}$ & $\stackrel{\infty}{\grave{g}}$ & & $\begin{array}{l}8 \\
\text { d } \\
\text { d } \\
\text { d }\end{array}$ & $\stackrel{\infty}{\stackrel{\rho}{\rho}}$ & in & $\underset{\substack{\text { N } \\
\text { fi }}}{ }$ & $\stackrel{\infty}{\underset{\exists}{\pi}}$ & 0 & ถู่ & $\begin{array}{l}\stackrel{\text { }}{h} \\
\stackrel{\text { A }}{ }\end{array}$ & $\stackrel{\infty}{\sim}$ & ఏ્ન & $\stackrel{\circ}{\sim}$ & รี \\
\hline & $\begin{array}{l}\text { gू } \\
\text { c్ } \\
\text { एँ }\end{array}$ & & $\begin{array}{l}\text { कै } \\
\text { जे } \\
\text { जे }\end{array}$ & ర్త & \begin{tabular}{l}
$\stackrel{m}{\infty}$ \\
\multirow{2}{*}{} \\
0
\end{tabular} & 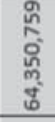 & ณิ & 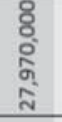 & $\begin{array}{l}\text { gे } \\
\text { ज़ } \\
\text { ğ } \\
\text { o }\end{array}$ & $\stackrel{\varpi}{\beth}$ & 品 & & 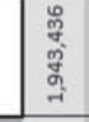 & ్ㅡㅁ & ส & 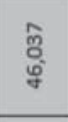 & $\overrightarrow{\overline{0}}$ & $\stackrel{+}{p}$ & $\stackrel{4}{6}$ & $\begin{array}{l}\text { స్ర్ } \\
\text { ధ్ర }\end{array}$ & : & ฮั่ & ㅇ & $\overrightarrow{0}$ \\
\hline & & 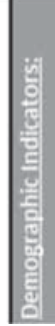 & 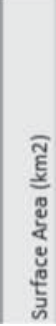 & 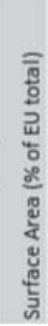 & 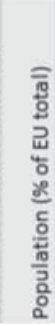 & $\frac{\mathrm{g}}{\frac{0}{0}}$ & 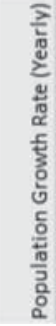 & 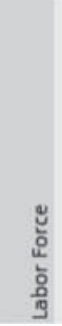 & 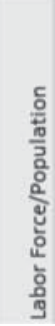 & 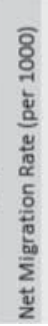 & $\begin{array}{l}\text { 吅 } \\
\text { 웜 }\end{array}$ & & 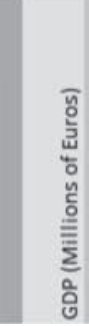 & 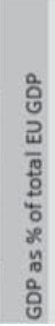 & 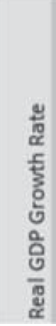 & 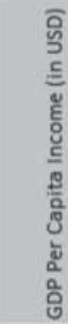 & 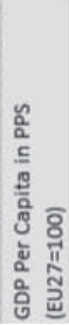 & 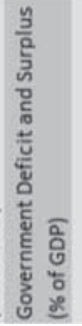 & & 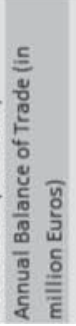 & 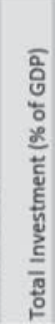 & 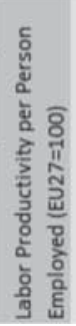 & 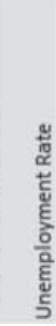 & 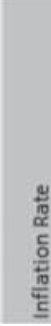 \\
\hline
\end{tabular}




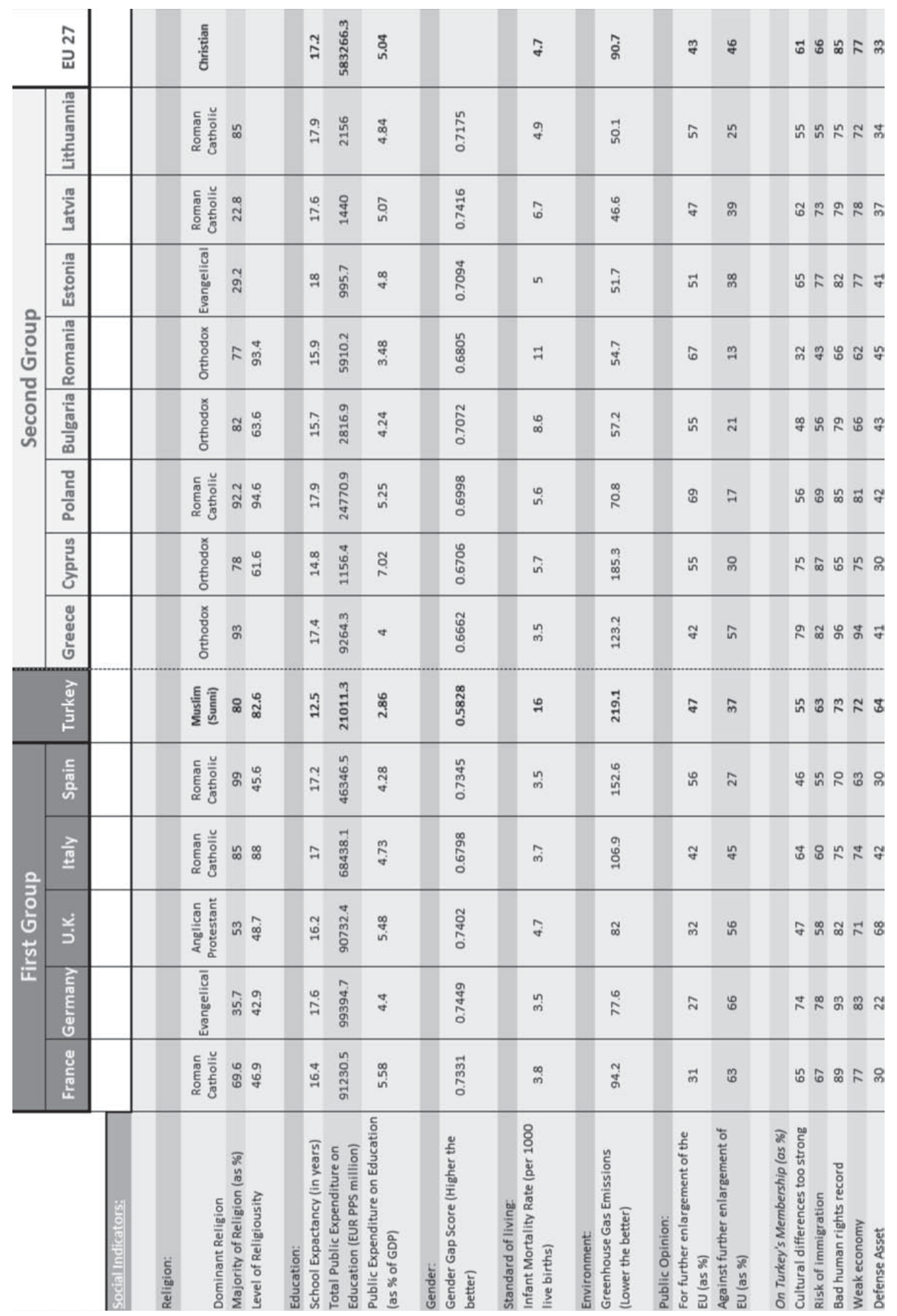




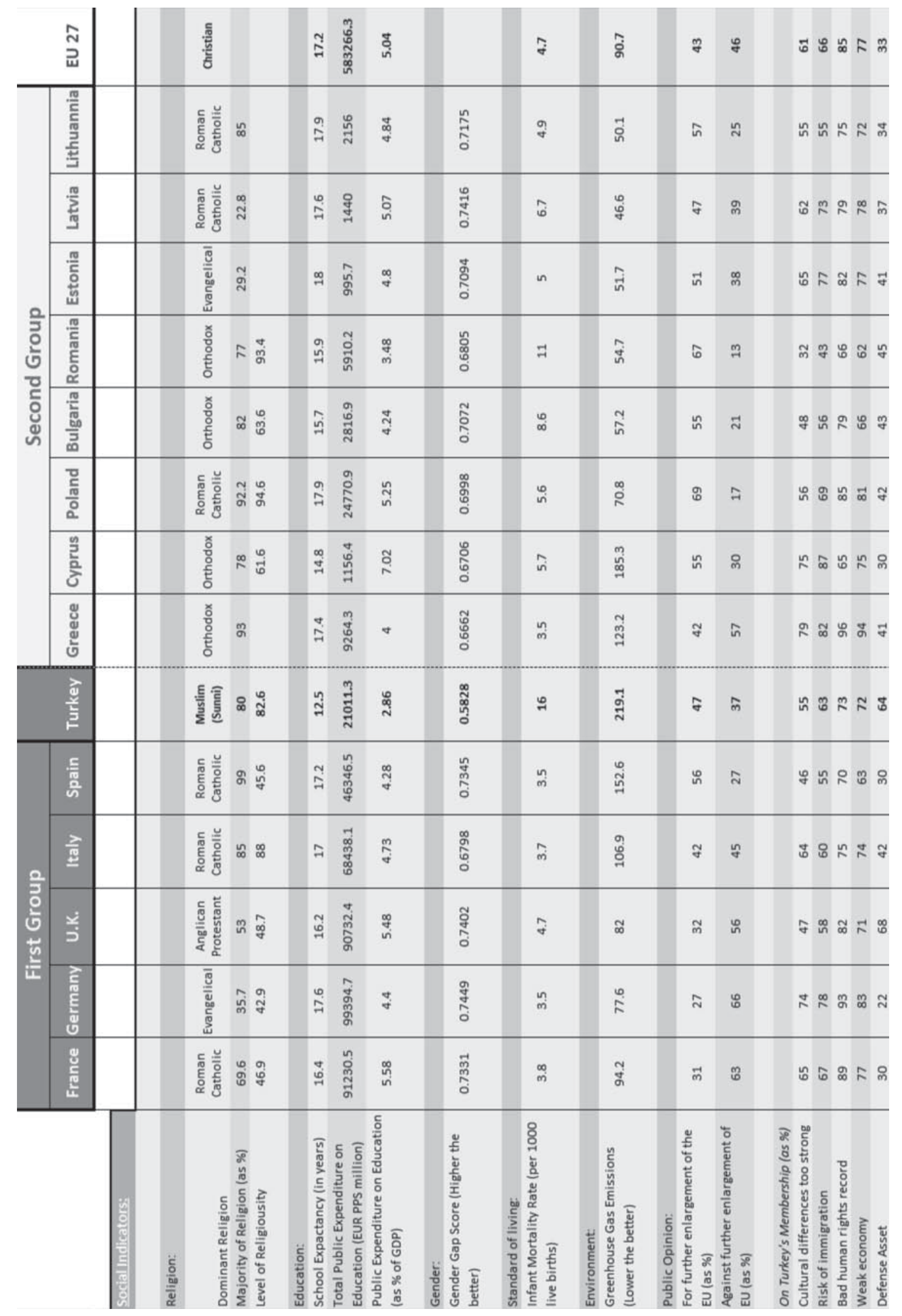




\section{APPENDIX B}

Online Data Sources and Printed Press References:

European Commission Eurostat:

http://epp.eurostat.ec.europa.eu/portal/page/portal/eurostat/home/

European Commission Public Opinion - Eurobarometer:

http://ec.europa.eu/public_opinion/index_en.htm

United Nations Statistics Department - UNdata:

http://data.un.org/

International Monetary Fund Data and Statistics:

http://www.imf.org/external/data.htm

United States of America Central Intelligence Agency - The World Factbook:

https://www.cia.gov/library/publications/the-world-factbook/

International Institute for Democracy and Electoral Assistance (International IDEA):

http://www.idea.int/vt/

World Values Survey:

http://www.worldvaluessurvey.org/

Freedom House - Freedom in the World Report 2009

http://www.freedomhouse.org/

The Economist Intelligence Unit's Index of Democracy 2008:

http://graphics.eiu.com/PDF/Democracy\%20Index\%202008.pdf

World Economic Forum - The Global Gender Gap Record 2009:

http://www.weforum.org/pdf/gendergap/report2009.pdf

KONDA Research and Consultancy. (2007). Religion, Secularism and the Veil in Daily Life Survey: http://www.konda.com.tr/en/reports.php?tb=2

BBC News:

http://www.bbc.co.uk/news/

Die Welt - German Daily Newspaper:

http://www.welt.de

Zaman - Turkish Daily Newspaper:

http://www.todayszaman.com

Financial Times:

http://www.ft.com 


\section{Sources and Year of Data according to Indicators:}

\begin{tabular}{|c|c|c|}
\hline Indicator & Year & Source \\
\hline \multicolumn{3}{|l|}{ Demographic Indicators: } \\
\hline Surface Area $(\mathrm{km} 2)$ & 2007 & Undata \\
\hline Surface Area ( $\%$ of EU total) & 2007 & Calculated \\
\hline Population (\% of EU total) & 2009 & Calculated \\
\hline Population & 2009 & Eurostat \\
\hline Population Growth Rate (Yearly) & 2009 & The World Factbook \\
\hline Labor Force & 2008 & The World Factbook \\
\hline Labor Force/Population & 2008 & Calculated \\
\hline Net Migration Rate (per 1000) & 2009 & Eurostat \\
\hline Median Age & 2009 & The World Factbook \\
\hline \multicolumn{3}{|l|}{ Economic Indicators: } \\
\hline GDP (Millions of Euros) & 2009 & Eurostat \\
\hline GDP as $\%$ of total EU GDP & 2009 & Calculated \\
\hline Real GDP Growth Rate & 2009 & Eurostat \\
\hline GDP Per Capita Income (in USD) & 2008 & IMF Statistics \\
\hline GDP Per Capita in PPS (EU27=100) & 2009 & Eurostat \\
\hline Government Deficit and Surplus (\% of GDP) & 2008 & Eurostat \\
\hline Public Debt (\% of GDP) & 2008 & Eurostat \\
\hline Annual Balance of Trade (in million Euros) & 2008 & Eurostat \\
\hline Total Investment (\% of GDP) & 2009 & Eurostat \\
\hline Labor Productivity per Person Employed (EU27=100) & 2009 & Eurostat \\
\hline Unemployment Rate & 2009 & Eurostat \\
\hline Inflation Rate & 2009 & Eurostat \\
\hline \multicolumn{3}{|l|}{ Political Indicators: } \\
\hline Political Party in Power & 2010 & Individually Collected \\
\hline Trust in National Government (as \%) & 2008 & Eurobarometer (71) \\
\hline Democracy Index (10: top score, 1: lowest score) & 2009 & Freedom House \\
\hline Political Rights (1: top score, 10: lowest score) & 2009 & Freedom House \\
\hline Civil Liberties (1: top score, 10: lowest score) & 2009 & Freedom House \\
\hline Voter Turnout on Parliamentary Elections (as\%) & 2007 & International IDEA \\
\hline Government Involvement in Religion (GIR) & $1990-2002$ & Fox, Jonathan (2008) \\
\hline \multicolumn{3}{|l|}{ Security Indicators: } \\
\hline Military Size & 2006 & Individually Collected \\
\hline Military Budget (in Billions of USD) & 2006 & Individually Collected \\
\hline Military Expenditure (\% of GDP) & 2005 & The World Factbook \\
\hline Members of NATO since & 201 & Individually Collected \\
\hline
\end{tabular}




\begin{tabular}{|c|c|c|}
\hline Indicator & Year & Source \\
\hline \multicolumn{3}{|l|}{ Social Indicators: } \\
\hline \multicolumn{3}{|l|}{ Religion: } \\
\hline Dominant Religion & 1990-2002 & Fox, Jonathan (2008) \\
\hline Majority of Religion (as \%) & $1990-2002$ & Fox, Jonathan (2008) \\
\hline Level of Religiosity & $2005-2007$ & World Values Survey \\
\hline \multicolumn{3}{|l|}{ Education: } \\
\hline School Expectancy (in years) & 2007 & Eurostat \\
\hline Total Public Expenditure on education (EUR PPS million) & 2006 & Eurostat \\
\hline Public Expenditure on Education (as \% of GDP) & 2006 & Eurostat \\
\hline \multicolumn{3}{|l|}{ Gender: } \\
\hline Gender Gap Score (Higher the better) & 2009 & World Economic Forum \\
\hline \multicolumn{3}{|l|}{ Health and standard of living: } \\
\hline Infant Mortality Rate (per 1000 live births) & 2008 & Eurostat \\
\hline \multicolumn{3}{|l|}{ Environment: } \\
\hline Greenhouse Gas Emissions (Lower the better) & 2007 & Eurostat \\
\hline \multicolumn{3}{|l|}{ Public Opinion: } \\
\hline For further enlargement of the EU (as \%) & 2009 & Eurobarometer (71) \\
\hline Against further enlargement of EU (as \%) & 2009 & Eurobarometer (71) \\
\hline \multicolumn{3}{|l|}{ On Turkey's Membership (as \%) } \\
\hline Cultural differences too strong & 2006 & Eurobarometer (66) \\
\hline Risk of immigration & 2006 & Eurobarometer (66) \\
\hline Human rights & 2006 & Eurobarometer (66) \\
\hline Economy & 2006 & Eurobarometer (66) \\
\hline Defense & 2006 & Eurobarometer (66) \\
\hline
\end{tabular}

